\begin{tabular}{|l|l|l|l|l|l|}
\hline MUNIBE Antropologia-Arkeologia & $n^{\circ} 70$ & $219-249$ & DONOSTIA & 2019 & ISSN 1132-2217 • eISSN 2172-4555 \\
\hline
\end{tabular}

\title{
Nuevos datos para el conocimiento de la Segunda Edad del Hierro en territorio cántabro: la vaguada del castro de Las Rabas (Cervatos, Cantabria)
}

\author{
New data for the knowledge of the Second Iron Age in cantabrian territory: \\ the valley of the hillfort of Las Rabas (Cervatos, Cantabria)
}

PALABRAS CLAVES: Cántabros, Cultura material, Cerámica, Edad del Hierro, Cráneo, Violencia. GAKO-HITZAK: Kantabriarrak, Kultura materiala, Zeramika, Burdin Aroa, Garezurra, Indarkeria. KEY WORDS: Cantabrian, Material culture, Pottery, Iron Age, Skull, Violence.

\section{Rafael BOLADO DEL CASTILLO(1), Pedro Ángel FERNÁNDEZ VEGA(2), Silvia CARNICERO ${ }^{(3)}$ y Emilio PÉREZ PUJOL ${ }^{(4)}$}

\section{RESUMEN}

Presentamos el estudio conjunto de los registros materiales procedentes de las distintas intervenciones realizadas en la vaguada del castro de las Rabas (Cervatos, Cantabria) en 1968-1969 y en 2011. Los resultados han permitido contribuir a caracterizar la cultura material del enclave, mientras que el estudio antropológico del cráneo conservado revela lesiones perimortales acontecidas en el siglo IV a.C., momento en el que el yacimiento pudo sufrir alguna incursión violenta.

\section{LABURPENA}

Rabaseko (Cervatos, Kantabria) kastroko ibarbidean 1968-1969an eta 2011n egindako lanetan jasotako erregistro materialen inguruko ikerlan bateratua aurkeztu dugu honekin batera. Emaitza horiei esker, gune hartako kultura materialaren ezaugarriak ondorioztatu ahal izan ditugu. Bestalde, jasotako garezurraren azterketa antropologikoak K.a. IV. mendean lesio perimortalak (heriotza unekoak) izan zituela erakusten du. Litekeena da une hartan aztarnategiak indarkeriazko erasoaldiren bat jasan izana.

\section{ABSTRACT}

In this paper, we present the material culture recorded in the hillfort of Las Rabas (Cervatos, Cantabria), between 1968-1969 and 2011. Our results allow us to characterize the material culture of the site and the anthropological study of the human skull shows perimortal injuries as consequence of a possible attack on the town in the 4th century a.C.

The valley of the hillfort of Las Rabas is one of the most important areas of the site because most of the archaeological materials come from here. The different studies have led to interpret the valley as one of the areas of habitat or as a possible necropolis. The materials recovered during the archaeological excavation of 2011 allow us to propose that it be a landfill. The study of the archaeological materials has allowed differentiating three types of pottery productions: handmade pottery, wheel made pottery and campanian pottery. This last type could be imitations. Also abundant remains of fauna bones have been recovered, a human skull and iron and bronze objects like arms and fibulae. All archaeological objects date the site in the Second Iron Age, being destroyed during Cantabrian Wars.

\section{INTRODUCCIÓN}

La Edad del Hierro en Cantabria constituye un momento de gran relevancia en la prehistoria de esta comunidad, y no solamente por las implicaciones científicas que tiene, sino por la gran aceptación social del periodo. No obstante parece existir una disociación involuntaria entre el interés público y el académico, siendo escasas las intervenciones arqueológicas y los estudios existentes, que suelen centrarse en aspectos poliorcéticos o en el episodio bélico de las Guerras Cántabras.

Como consecuencia, actualmente sigue pendiente una caracterización de la cultura material de las poblaciones de la Edad del Hierro en Cantabria que permita ahondar en aspectos económicos, sociales, políticos, o establecer análisis comparativos con los territorios

\footnotetext{
(1) Instituto Internacional de Investigaciones Prehistóricas de Cantabria- IIIPC (Universidad de Cantabria, Gobierno de Cantabria, Santander). (2) UNED-Cantabria y Vizcaya.

(3) Médico Forense, Patólogo y Antropólogo. Instituto de Medicina Legal de Cantabria

(4) Médico Forense jubilado. Exdirector del Instituto de Medicina Legal de Murcia.
} 
próximos. Estudios como el presente, en el que se realiza un análisis conjunto de distintos registros materiales de un mismo yacimiento, pretenden paliar esta carencia, contribuyendo no solo a mejorar el conocimiento que se tiene del poblado, sino de la Edad del Hierro en el norte peninsular.

Entre 1968 y 1969 se realizaron las primeras excavaciones en el castro de Las Rabas (Cervatos, Cantabria) bajo la dirección de Miguel Ángel García Guinea. Un castro de unas 10 ha, con defensas levantadas a partir de aterrazamientos con lienzo externo y murallas de doble paramento, y una zona de hábitat posiblemente dispersa por las cotas más elevadas, que hunde sus raíces en el siglo IV a.C. hasta encontrar su final durante las Guerras Cántabras (García Guinea y Rincón, 1970; Bolado y Fernández Vega, 2010; Fernández Vega et al., 2012).

Durante estos dos años se abrieron un total de diez catas que permitieron recuperar un amplio conjunto de materiales. Cuatro de estas catas (Cata 3A, 3B, 3C y Cata Tierra Julia), en un intento de obtener una secuencia estratigráfica sólida, fueron replanteadas en la vaguada sureste, entre la cima de Las Rabas y el Alto de la Mayuela. Una zona que, en tiempo modernos, fue aprovechada para la plantación de patatas, conservándose aún hoy varios aterrazamientos agrícolas (Fig. 1).

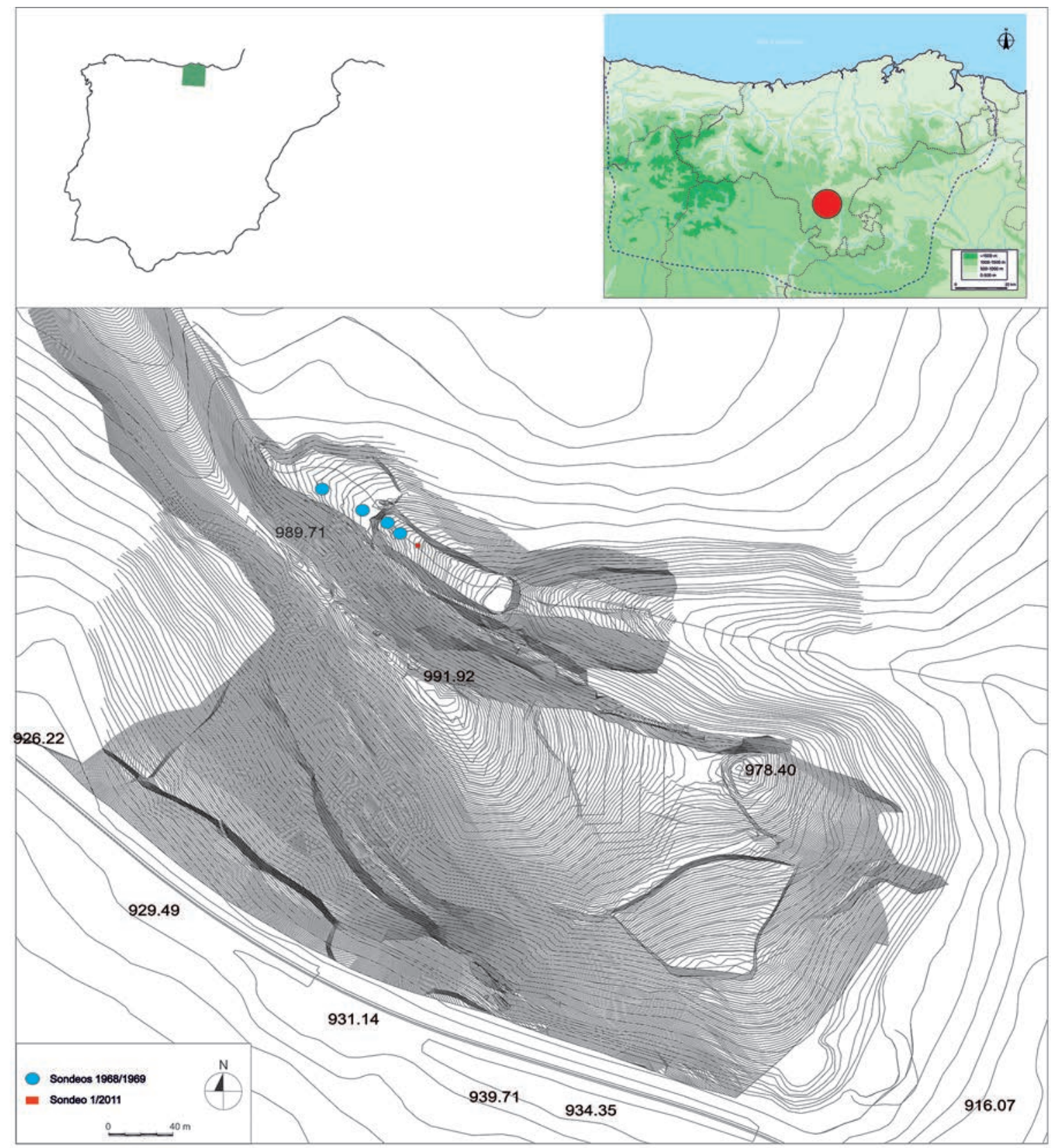

Fig. 1. Localización del castro de Las Rabas (Cervatos, Cantabria). / Location of Las Rabas hillfort. 
Según refieren García Guinea y Rincón, en todas las Catas 3, "a pesar de profundizar en una... hasta más de 2 metros, los restos arqueológicos aparecidos tienen todos idéntica factura y características". Esta misma conclusión se extrae del análisis que realizan de forma individualizada de las tres catas. En la Cata 3A observan "niveles de ceniza alternando con tierra y arcilla rojiza, como quemada". Si bien, desde los $20 \mathrm{~cm}$ y hasta los $2,2 \mathrm{~m}$, no se detectan variaciones en el material, recogiéndose junto a diversos elementos de guarnicionería de bronce o una fíbula de aro sin resorte "omega", abundante cerámica a mano y cerámica oxidante a torno, la cual aparece en menor proporción (García Guinea y Rincón, 1970: 14). Esto les lleva a concluir que únicamente existe un único nivel arqueológico que se asienta sobre arcillas grises estériles (García Guinea y Rincón, 1970: 15). En la Cata 3B y $3 \mathrm{C}$ se repiten las mismas pautas, alcanzándose potencias de más de dos metros que, casi desde el nivel superficial proporcionan materiales de similares características como cerámica a mano y cerámica a torno oxidante, fragmentos de cuchillos, un ejemplar afalcatado completo, restos de mangos de asta, elementos de guarnicionería, una hebilla en "D" y dos tipos de fíbulas: La Tène o de apéndice caudal y de aro sin resorte "omega".

La Cata Tierra Julia, aun distando ligeramente de las anteriores, no se aleja de lo descrito (García Guinea y Rincón, 1970: 18), destacando el conjunto cerámico, una fíbula La Tène o de apéndice caudal, dos fíbulas de aro sin resorte "omega" y los restos de un cráneo humano (García Guinea y Rincón, 1970: 36, Lám. XXIII y XIV).

Todo ello obligó a incluir la zona en la interpretación general del yacimiento, la cual sostenía que todo el material aparece en un único nivel estratigráfico, sin aportes anteriores o posteriores a los siglos II-I a.C. (García Guinea, 1999: 101).

En el año 2011, en el marco de las intervenciones dirigidas por P.A. Fernández Vega, con el apoyo de la Consejería de Educación, Cultura y Deporte del Gobierno de Cantabria, el Servicio Cántabro de Empleo, los Ayuntamientos de Campoo de Enmedio y de Valdeolea y el Taller de Empleo Valdeolea, se procedió a realizar un sondeo en la zona situada entre las Catas 3 y la Cata Tierra Julia (Fig. 1). El objetivo del mismo era intentar documentar el uso de la vaguada, con el fin de corroborar o desechar las distintas interpretaciones propuestas desde 1970: zona de hábitat (Rincón, 1985: 186; Fraile, 1990: 132), necrópolis (Ruiz y Muñoz, 2010: 651) o vertedero (Bolado et al., 2010; Bolado y Fernández Vega, 2010: 409). De forma simultánea, dentro del proyecto de investigación "La cultura material de la Edad del Hierro en Cantabria" Ilevado a cabo por $\mathrm{R}$. Bolado del Castillo, se realizó una revisión de todo el material procedente de las campañas de 1968 y 1969, que posibilitó comparar ambos registros extrayendo así la mayor información posible.

\section{EL REGISTRO MATERIAL DE LA VAGUADA DE LAS CAMPAÑAS DE 1968-1969}

El estudio del material se afrontó atendiendo a la materia prima de las piezas (cerámica, hierro, bronce, lítica, etc.) con la única salvedad del escaso material romano, el cual se ha agrupado en un subapartado independiente. Esta decisión se ha tomado para evitar confusiones ya que el yacimiento, por el momento, carece de niveles de ocupación romanos, debiéndose relacionar estos restos, por su marcado origen militar, con las Guerras Cántabras. Para las producciones cerámicas se ha tomado como unidad de análisis el fragmento, centrándonos en sus rasgos tecnológicos, morfológicos, decorativos y funcionales, en continuidad con estudios precedentes (Bolado et al., 2015). Los datos métricos se han extraído de las partes que, desde el punto de vista morfológico, aportan más información: bordes, cuellos y bases; descartando, en el caso de los grosores, aquellas que no conservan ambas superficies. La tipología de las mismas se ha basado en el trabajo de Caro (2006) (Fig. 2). Las fíbulas se

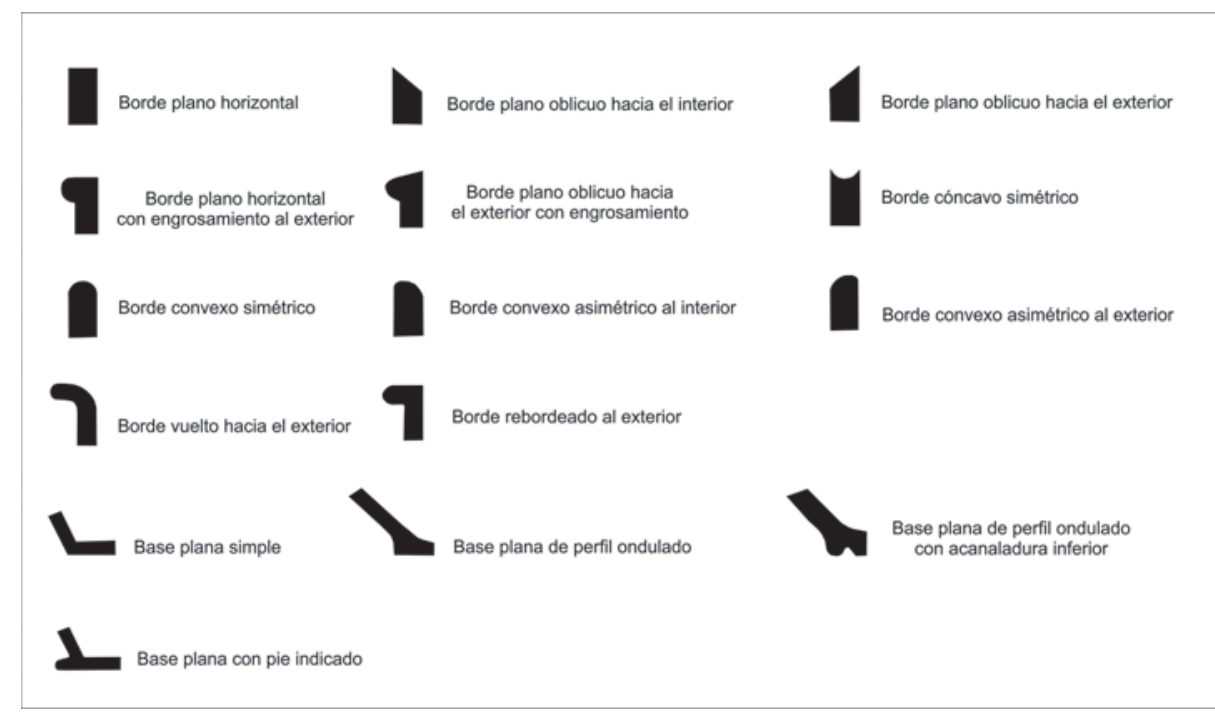

Fig. 2. Tipos de bordes y bases identificadas (Dibujo a partir de Caro, 2006). / Tips of lip and base (Drawing base on Caro, 2006). 
han estudiado a partir de los trabajos de Erice (1995), Argente (1994) y Mariné (2001), mientras que el resto de piezas se han analizado a partir de su identificación formal/funcional.

El estudio de la colección ha estado condicionado por la falta de inventario, lo que nos obligó a tomar como referencia las etiquetas de las bolsas y las siglas, las cuales se han conservado en unos pocos casos. Aunque algunas de ellas hacen referencia a una indefinida "Área 3", "Cata 3" o "Cata Tierra", parece claro que proceden de la vaguada, bien de las Catas 3A, 3B o 3C, o bien de la Cata Tierra Julia, por lo que no se disociaron del registro.

Acorde con la interpretación estratigráfica del yacimiento del momento, no existe información alguna sobre niveles estratigráficos, por lo que hemos procedido a realizar el estudio de materiales de forma conjunta. El aporte procedente de cada cata puede observarse en la figura 3, dividiéndose el registro de la siguiente forma: el 87,22\% ( $n=1126)$ lo compone la colección cerámica, el 4,72\% ( $n=61)$ los objetos de hierro, el 4,10\% $(n=53)$ los restos de bronce, el 2,17\% $(n=28)$ los restos de asta y el 1,08\% $(n=14)$ la fauna. En proporciones inferiores al $1 \%$ encontramos material constructivo $(n=1)$, numismática $(n=2)$, material militar romano $(n=4)$, un resto lítico y un cráneo humano.

\subsection{La producción cerámica}

La colección se compone de 1126 fragmentos entre los que se distinguen tres tipos de producciones: cerámica a mano, cerámica a torno y cerámica campaniense.

La cerámica a mano supone un 81,17\% $(n=914)$. Desde el punto de vista tecnológico los 117 bordes presentan un grosor medio de $7,32 \pm 8,13 \mathrm{~mm}$ y las bases de 9,18 $\pm 3,53 \mathrm{~mm}$ (Tab. 1). Todos los fragmentos conservan trazas propias de una manufactura a mano, habiendo sido cocidos en atmósferas alternantes en el $60,95 \%$ de los casos, reductoras en el 38,50\% y oxidantes en el $0,55 \%$. En la mayor parte de las piezas las superficies conservan evidencias de haber sido sometidas a distintos tratamientos. El regularizado es el más frecuente, documentándose en el 79,76\% de las superficies exteriores y en el $87,35 \%$ de las interiores. El raspado aparece en el 9,79\% de las superficies exteriores y en el $10,67 \%$ de las interiores, el bruñido en el $7,81 \%$ de las superficies exteriores y en el $0,66 \%$ de las interiores y el espatulado en el $0,77 \%$ de las superficies exteriores y en el $0,11 \%$ de las interiores. Existen tratamientos múltiples que combinan el bruñido y el raspado en el 0,44\% de las superficies exteriores y en el $0,11 \%$ de las interiores y el bruñido y el espatulado en el $1,21 \% \%$ de las superficies exteriores y en el $0,11 \%$ de las interiores (Tab. 2).

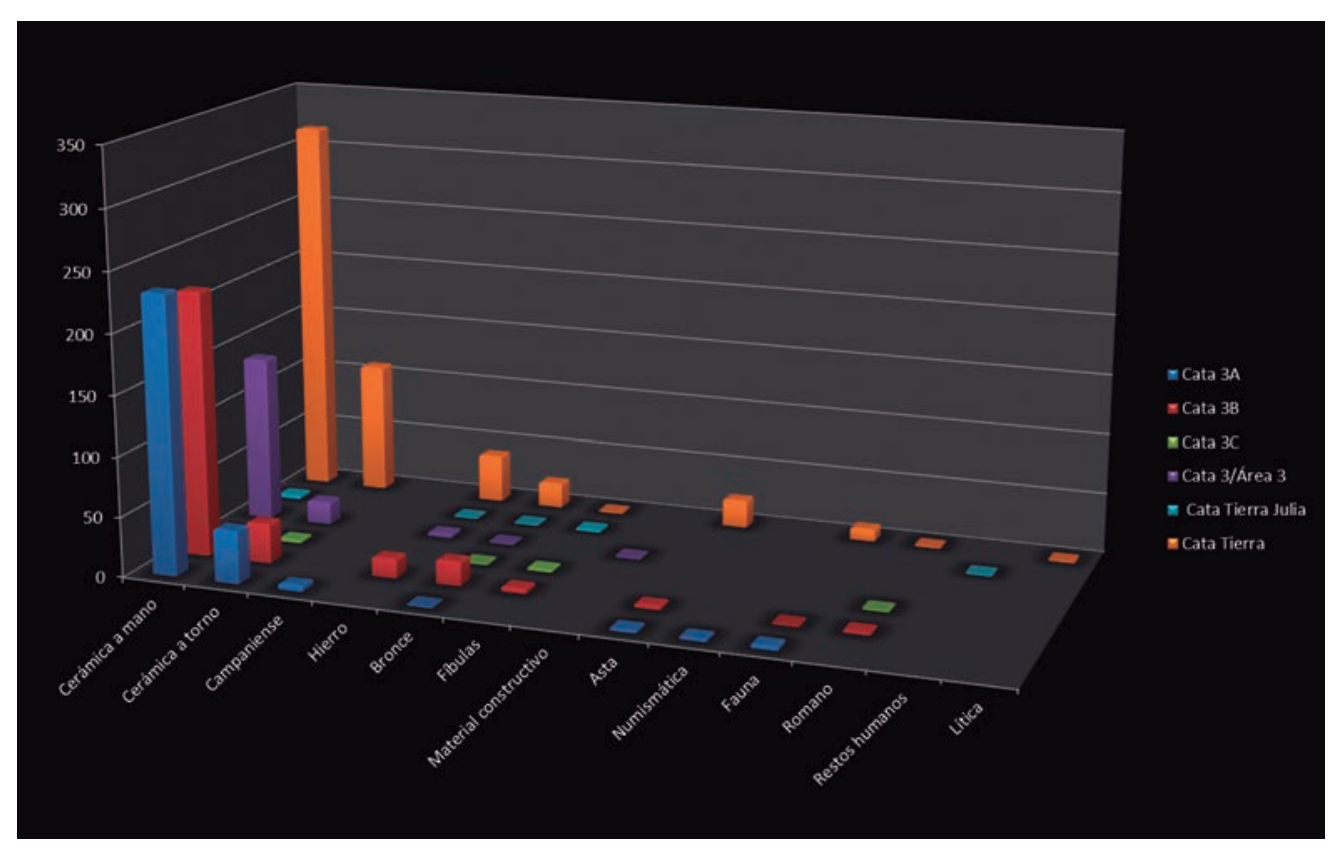

Fig. 3. Distribución de materiales por catas. / Archaeological material distribution by trials excavations.

\begin{tabular}{|c|c|c|c|}
\hline Parte morfológica & Número de restos & Grosor $(\mathbf{m m})$ & Desviación típica \\
\hline Borde & 114 & 7,32 & 8,13 \\
\hline Base & 29 & 5,72 & 1,25 \\
\hline Cuello & 53 & 9,18 & 3,53 \\
\hline TOTAL & 196 & - & - \\
\hline
\end{tabular}

Tabla 1: Grosor medio en función de las distintas partes morfológicas. / Average thickness according to the different morphological parts. 


\begin{tabular}{|c|c|c|c|c|c|c|c|}
\hline \multicolumn{7}{|c|}{ Tratamiento superficial exterior } \\
\hline Bruñido-Espatulado & Bruñido-Raspado & Bruñido & Raspado & Espatulado & Regularizado & No se conserva & TOTAL \\
\hline 12 & 3 & 71 & 89 & 7 & 725 & 7 & 914 \\
\hline \multicolumn{7}{|c|}{ Tratamiento superficie interior } \\
\hline Bruñido-Raspado & Bruñido & Raspado & Espatulado & Regularizado & No se conserva & TOTAL \\
\hline 2 & 6 & 97 & 1 & 794 & 14 & 914 \\
\hline
\end{tabular}

Tabla 2: Tratamientos superficiales. / Surface treatments.

A nivel morfológico la parte más representada es el galbo $(71,33 \%)$, seguida de los bordes $(12,8 \%)$, las bases $(7 \%)$ y los cuellos $(5,58 \%)$. Entre los elementos complementarios encontramos asas $(2,52 \%)$ y tapaderas $(0,22 \%)$, restando un $0,55 \%$ compuesto por fichas perforadas (Fig. 4). Dentro de los bordes hay un predominio del grupo de bordes planos $(71,79 \%)$, en donde encontramos planos horizontales $(41,88 \%)$, planos biselados al exterior (17,95\%), planos horizontales con engrosamiento al exterior $(7,69 \%)$ y planos biselados al interior $(4,27 \%)$. Los bordes redondeados constituye el $24,79 \%$ del total, identificándose redondeados simétricos (19,66\%), redondeados asimétricos al interior $(3,42 \%)$ y redondeados asimétricos al exterior $(1,71 \%)$. De forma aislada tenemos un borde cóncavo simétrico, un borde vuelto hacia el exterior, un borde rebordeado al exterior y un borde indeterminable. La tendencia es bastante diversa siendo recta en el $41,88 \%$ de los casos, exvasada en el $33,33 \%$, entrante en el $21,37 \%$ e indeterminada en el 3,42\%.

Las 64 bases son todas planas. Un 45,31\% forman parte del tipo simple y un $29,69 \%$ de las de perfil ondulado, mientras que las de pie indicado y de perfil ondulado con acanaladura inferior están representadas en un caso cada una. El 21,87\% no ha podido ser determinado.

Dentro de los elementos complementarios se documentan dos fragmentos de tapadera, de $12 \mathrm{~cm}$ y $15 \mathrm{~cm}$ de diámetro, y 23 asas (Fig. 5). A partir de su sección pueden clasificarse en circulares $(26,09 \%)$, rectangulares $(21,74 \%)$, elípticas $(13,04 \%)$, trilobuladas $(13,04 \%)$, bilobuladas $(8,7 \%)$ y triangulares $(4,35 \%)$; siendo indeterminables tres. Una de ellas conserva en la superficie una decoración impresa a base de estampillados rectangulares con líneas verticales paralelas.

El porcentaje de piezas que conservan motivos decorativos es muy bajo, constituyendo el 6,13\% (Tab. 3). En todos los casos se realizan sobre la superficie exterior y se localizan en la mitad superior de los cuerpos o, de forma marginal, en los bordes (Tab. 4). Las técnicas documentadas son la impresión $(57,14 \%)$, la incisión $(26,79 \%)$ y las aplicaciones plásticas (5,36\%), bien de forma individual o mediante su combinación (10,71\%). La impresión está representada por digitaciones, acanaladuras realizadas con el dedo, impresiones con instrumento, estampillados de sectores circulares, estampillados circulares, estampillados triangulares y es-

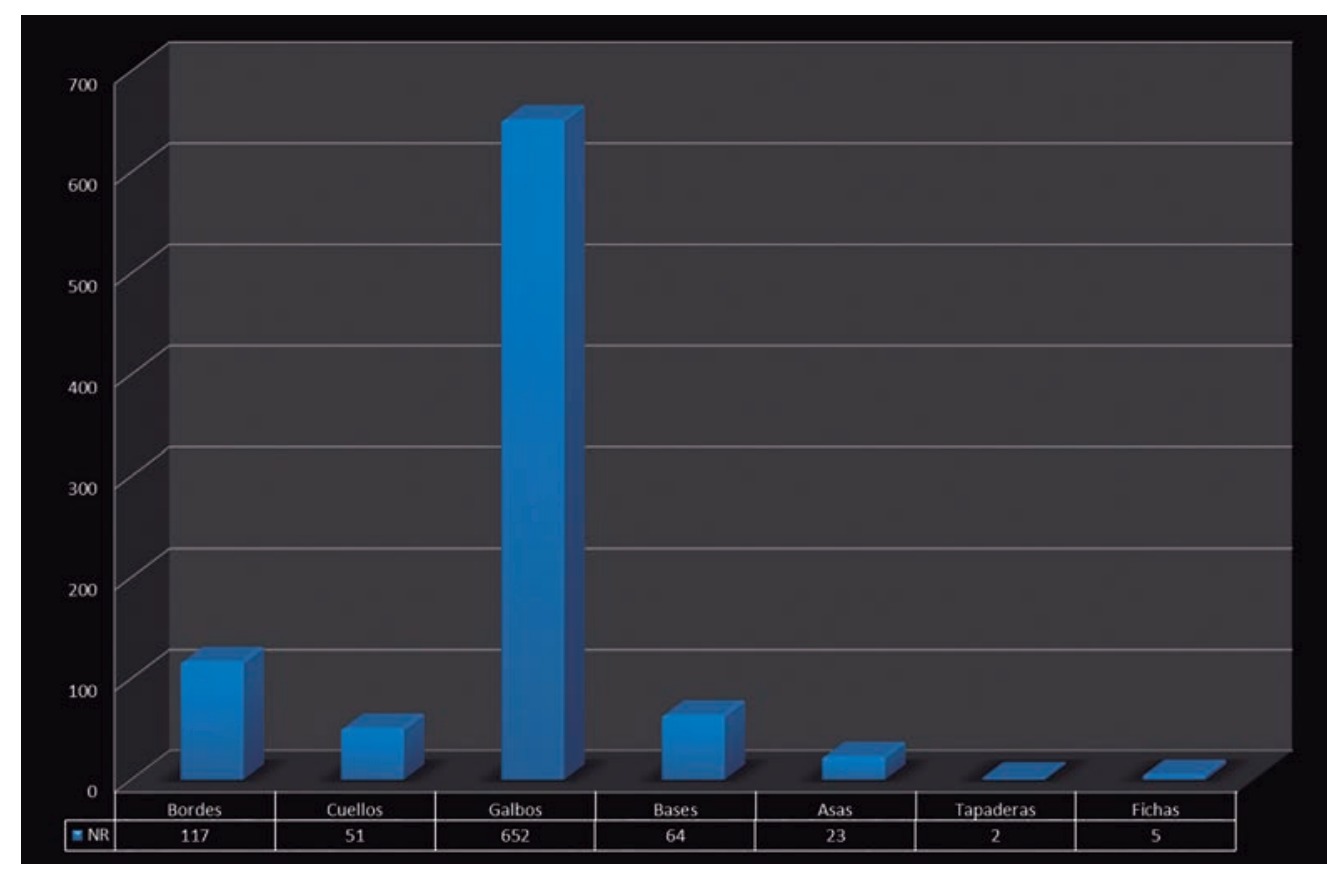

Fig. 4. Partes morfológicas. / Morphological parts of prerroman handmade pottery. 

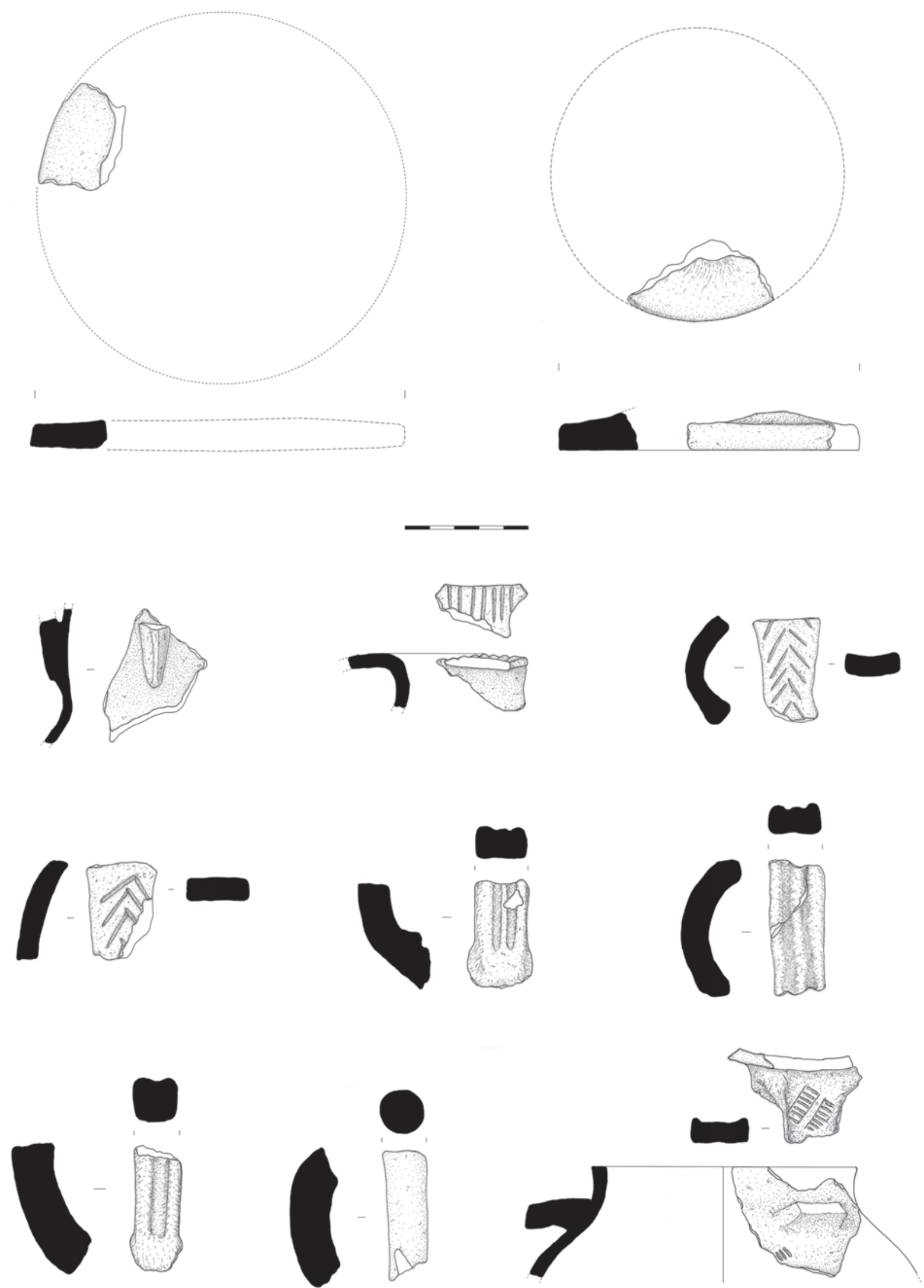

Fig. 5. Tapaderas y asas de las campañas de 1968-1969. (Dibujos: R. Bolado del Castillo). / Lids and handles of 1968-1969 (Drawing: R. Bolado del Castillo). 


\begin{tabular}{|c|c|c|}
\hline \multirow{15}{*}{ 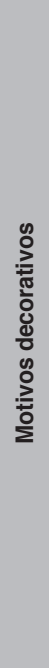 } & Digitaciones & 10 \\
\hline & Acanaladuras con el dedo & 8 \\
\hline & Impresas con instrumento & 3 \\
\hline & Estampillado triangular & 1 \\
\hline & Estampillado sectores circulares & 7 \\
\hline & Estampillado circular & 1 \\
\hline & Estampillado rectangular con líneas verticales paralelas & 1 \\
\hline & Incisiones en labio y estampillado & 1 \\
\hline & Incisiones lineales & 4 \\
\hline & Incisiones en V invertida & 11 \\
\hline & Incisiones en V invertida y estampillado circular & 5 \\
\hline & Mamelones & 1 \\
\hline & Cordones & 2 \\
\hline & Puntillado y pellizcos & 1 \\
\hline & TOTAL & 56 \\
\hline
\end{tabular}

Tabla 3: Decoraciones. / Decorations.

\begin{tabular}{|l|c|c|c|c|c|}
\cline { 2 - 6 } \multicolumn{1}{c|}{} & \multicolumn{5}{c|}{ Decoración } \\
\cline { 2 - 6 } \multicolumn{1}{c|}{} & Impresión & Incisión & Impresión e incisión & Plástica & TOTAL \\
\hline Borde & - & 1 & 1 & - & 2 \\
\hline Galbo & 31 & 11 & 5 & 2 & 49 \\
\hline Asa & 1 & 3 & - & 1 & 5 \\
\hline TOTAL & 32 & 15 & 6 & 3 & 56 \\
\hline
\end{tabular}

Tabla 4: Localización de las decoraciones. / Location of decorations.

tampillados rectangulares con líneas verticales paralelas (Fig. 6, 1). La incisión desarrolla motivos de "V" invertidas (individuales o en paralelo), lineales y de líneas paralelas en el labio (Fig. 6, 2). La decoración plástica se centra en mamelones y cordones (Fig. 6, 3). En tres casos se combinan las "V" invertidas incisas y los estampillados circulares, restando una pieza con incisiones en el labio y estampillas de sectores circulares y un ejemplar donde el puntillado acompaña a los pellizcos (Fig. 6, 4).

El grado de fragmentación del conjunto es bastante elevado, lo que imposibilita la reconstrucción de perfiles completos, salvo en dos casos, donde se alcanza una alta proporción. A pesar de ello podemos realizar un acercamiento a partir de algunos de los elementos morfológicos más característicos. De esta forma conocemos que las bocas oscilan entre los $8 \mathrm{~cm}$ y los $24 \mathrm{~cm}$ de diámetro mientras que las bases lo hacen entre los 5 $\mathrm{cm}$ y los $29 \mathrm{~cm}$. Las formas que se crean son mayoritariamente cerradas (Tab. 5).

\begin{tabular}{|l|c|c|c|c|c|c|}
\cline { 2 - 7 } \multicolumn{1}{c|}{} & \multicolumn{7}{c|}{ Diámetros (cm) } \\
\cline { 2 - 8 } \multicolumn{1}{c|}{} & $\begin{array}{c}\text { Tramo } \\
1-5\end{array}$ & $\begin{array}{c}\text { Tramo } \\
6-10\end{array}$ & $\begin{array}{c}\text { Tramo } \\
11-15\end{array}$ & $\begin{array}{c}\text { Tramo } \\
16-20\end{array}$ & $\begin{array}{c}\text { Tramo } \\
21-25\end{array}$ & $\begin{array}{c}\text { Tramo } \\
26-30\end{array}$ \\
\hline Boca(n) & - & 12 & 31 & 17 & 2 & - \\
\hline Base(n) & 1 & 20 & 7 & 1 & - & 2 \\
\hline
\end{tabular}

Tabla 5: Diámetros de bocas y bases. / Lips and bases diameter.
A nivel tipológico, junto a las dos tapaderas, es posible distinguir siete formas:

- Vasos o pequeñas vasijas cerradas de cuello exvasado y cuerpo de tendencia esférica. Este tipo está representado por un borde plano biselado al exterior con tendencia exvasada de $13,2 \mathrm{~cm}$ de diámetro de boca, que conserva una decoración a base de dos líneas de incisiones paralelas en "V" rematadas, en la parte inferior, por estampillados circulares (Fig. 7, 1). Existen otros dos bordes que podrían pertenecer a variantes de esta forma. En ambos casos muestran un borde plano oblicuo biselado al exterior de tendencia exvasada cuyos cuerpos parecen desarrollar formas ovoides. Tienen un diámetro de boca de $9,6 \mathrm{~cm}$ y $10,8 \mathrm{~cm}$ y una decoración en el cuerpo a base de dos líneas de incisiones paralelas en "V" (Fig. 7, 2 y 3). Con vasos o pequeñas vasijas pueden relacionarse también tres galbos de adscripción genérica, uno de ellos claramente esférico. Tienen un diámetro de cuerpo de $8,6 \mathrm{~cm}$ y $12 \mathrm{~cm}$ y conservan una decoración impresa a base de digitaciones (Fig. 7, 4 a 6).

- Cuencos. Dentro de esta forma encontramos un borde plano con cuerpo hemiesférico de 16,4 cm de diámetro de boca (Fig. 7, 9); un borde redondeado con tendencia recta, que parece formar parte de un cuenco de $12,8 \mathrm{~cm}$ de boca, con cuerpo hemiesférico (Fig. 7, 8); y un borde plano con tendencia recta de 11,2 cm de diámetro (Fig. 7, 7).

- Tazas. Contamos con un ejemplar de 10,4 cm de diámetro de boca. Posee un borde redondeado asimétrico al interior y tendencia exvasada, que conserva los arranques de un asa y una decoración en el cuerpo a base de dos líneas longitudinales de impresiones con instrumento a modo de uñadas (Fig. 7, 10).

- Jarras. Hemos documentado un ejemplar con asa con decoración sogueada, que carece de base y borde, aunque se aprecia que tuvo una tendencia exvasada. El cuerpo, de $12,5 \mathrm{~cm}$ de diámetro máximo, adquiere forma de elipsoide horizontal (Fig. 7, 11). Otro posible ejemplar está formado por un borde plano de $9 \mathrm{~cm}$ de diámetro de boca con cuello vertical y cuerpo hemiesférico o romboidal, de donde parte un asa de sección rectangular con decoración estampillada (Fig. 7, 12). Tampoco debemos desestimar la vinculación con este tipo de un pequeño borde con arranque de asa de sección trilobulada (Fig. 7, 13).

- Vasijas cerradas de cuello vertical y hombro pronunciado que tienden hacia un cuerpo globular u ovoidal. Están representadas por un borde plano con un diámetro de boca de 13,8 cm (Fig. 7, 17); un borde plano horizontal con arranque del cuerpo de $16,2 \mathrm{~cm}$ de diámetro de boca, que desarrolla bajo el hombro una decoración a base de incisiones paralelas en "V" invertidas con estampillado circular 


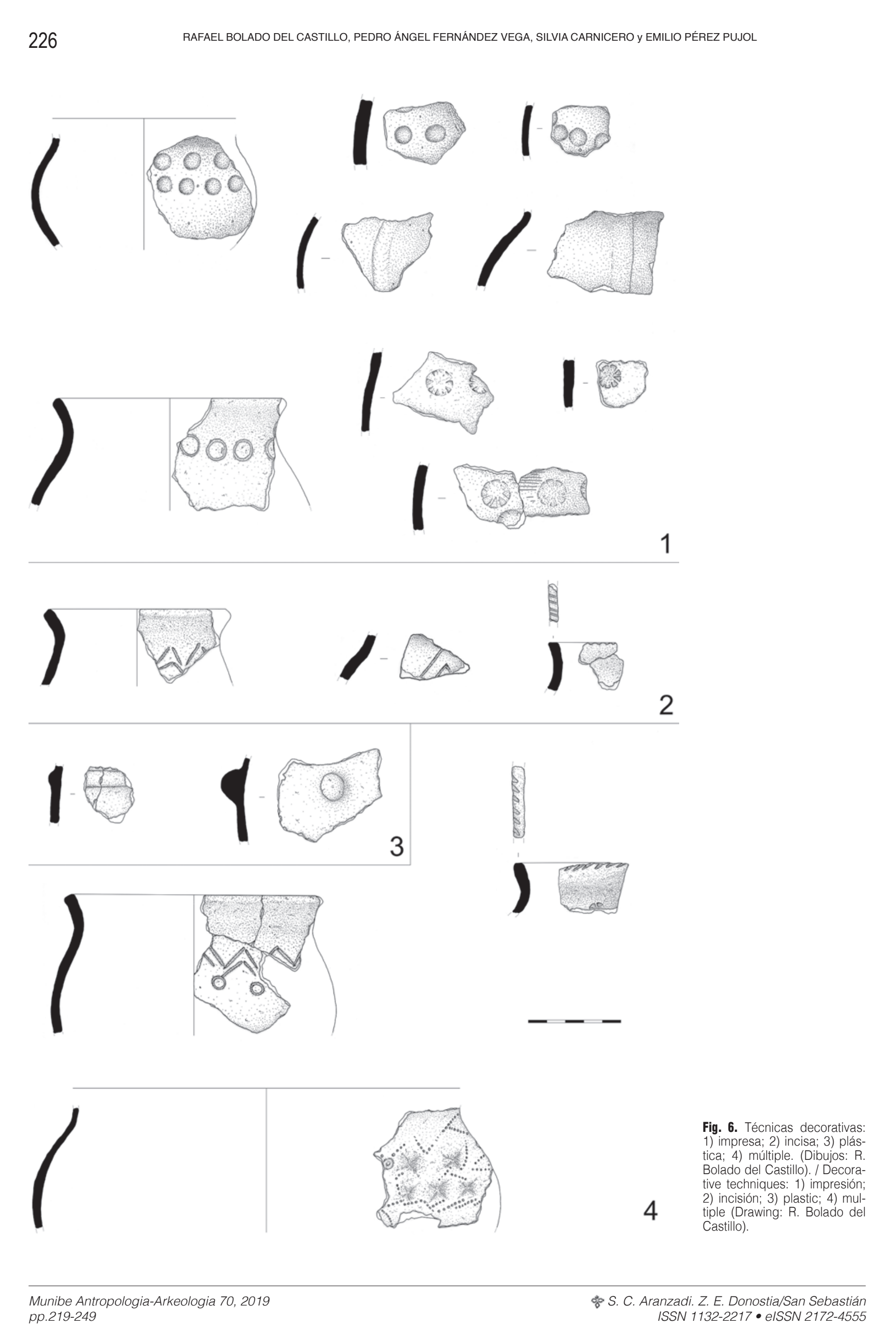



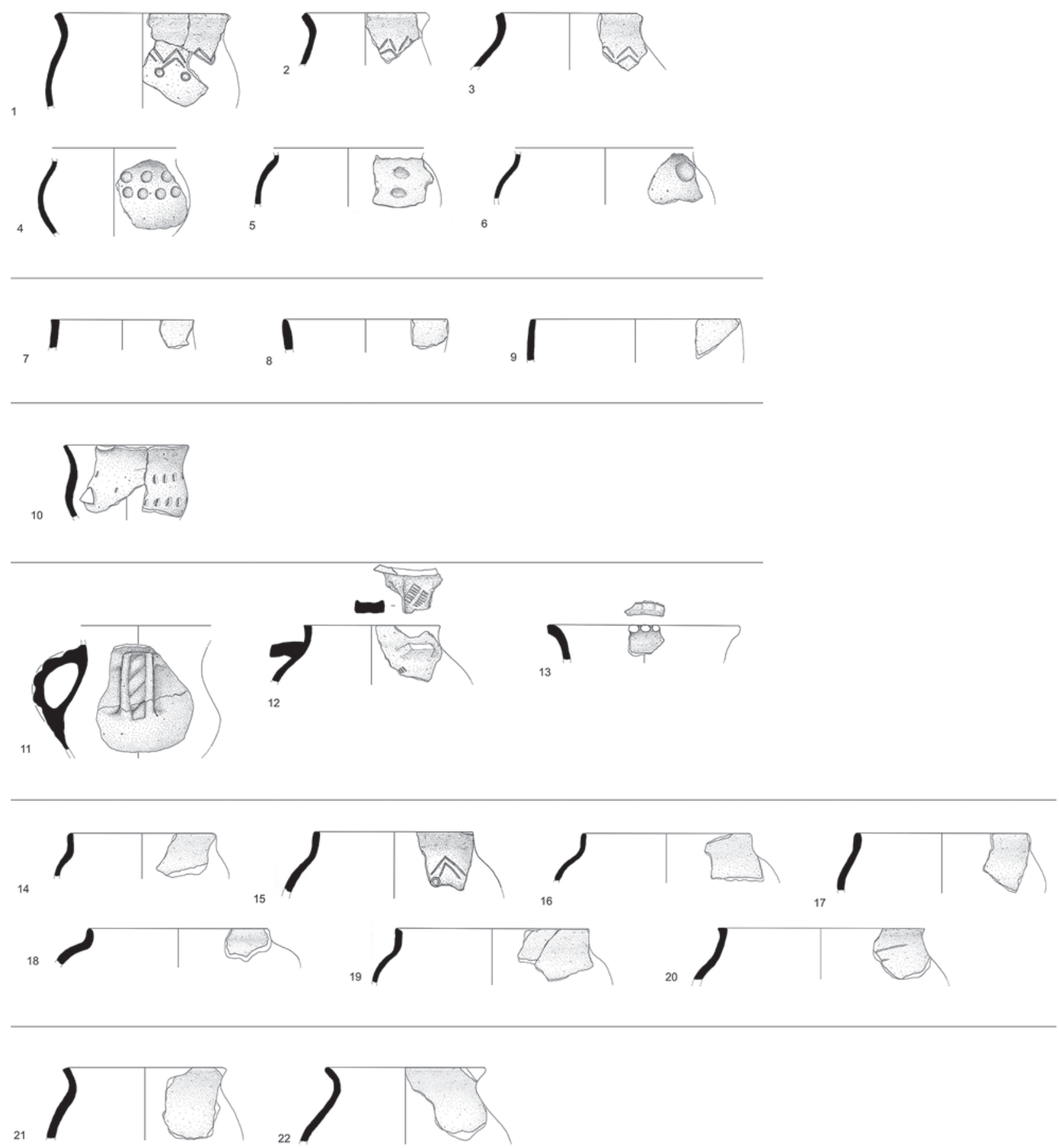

23

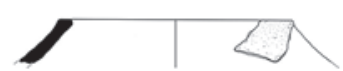

Fig. 7. Formas cerámica a mano prerromana de las campañas de 1968-1969. (Dibujos: R. Bolado del Castillo). / Shapes of prerroman handmade pottery (Drawing: R. Bolado del Castillo). 
en su extremo inferior (Fig. 7, 15); un borde plano biselado al interior de $15,4 \mathrm{~cm}$ de diámetro de boca (Fig. 7, 18); dos bordes redondeados y otro redondeado asimétrico al exterior de $14,4 \mathrm{~cm}, 11,2 \mathrm{~cm}$ y $13 \mathrm{~cm}$ de diámetro de boca (Fig. 7, 19, 14 y 16); y un ejemplar con tendencia ligeramente entrante, formado por un borde plano de 16,4 cm de boca, que muestra en el cuello y cuerpo dos incisiones diagonales paralelas (Fig. 7, 20).

- Vasijas cerradas de cuello exvasado y cuerpos de tendencia globular u ovoidal. Contamos en este grupo con un borde redondeado y otro plano biselado al exterior, con diámetros de boca de 13,6 $\mathrm{cm}$ y $13 \mathrm{~cm}$ respectivamente (Fig. 7, 21 y 22); y un borde redondeado de $12 \mathrm{~cm}$ de diámetro, que desarrolla una decoración impresa a base de una línea de círculos estampillados (Fig. 6,1).

- Vasijas cerradas de pronunciada tendencia entrante. Existe un solo ejemplar representado por un borde plano de $11,8 \mathrm{~cm}$ de diámetro (Fig. 7, 23).

Resta por último citar la documentación de cinco fichas perforadas realizadas a partir de galbos.

La segunda producción cerámica más representada es la cerámica a torno que, con 207 fragmentos, supone el $18,38 \%$. Al contrario de lo que sucede con la producción a mano, el número de bordes y bases es muy reducido (nueve y tres respectivamente) por lo que los datos métricos no son muy significativos. Los bordes presentan un grosor medio de $7,55 \pm 2,55 \mathrm{~mm}$ y las bases de $7 \pm 3,46 \mathrm{~mm}$. Todas las piezas muestran claras trazas de su modelado a torno y una tonalidad rojo-anaranjada propia de la cocción en atmósferas oxidantes.

El tratamiento superficial, ausente en tres superficies interiores, está protagonizado por el regularizado (96,62\% de las superficies exteriores y $94,20 \%$ de las interiores), seguido de forma minoritaria por el bruñido $(1,45 \%$ de las superficies exteriores) y el raspado $(1,93 \%$ de las superficies exteriores y $4,35 \%$ de las interiores (Tab. 6).

La parte más representada en esta producción es el galbo (92,75\%), quedando los bordes relegados al $4,35 \%$, las bases al 1,45\% y los cuellos al 1,45\% (Fig. 8). Entre los bordes el grupo de bordes redondeados alcanza el $77,8 \%$, distinguiéndose redondeados simétricos (44,44\%), asimétricos al interior (22,22\%) y asimétricos al exterior (11,11\%). Así mismo contamos con un ejemplar de borde rebordeado al exterior y otro indeterminado. La tendencia predominante es la exvasada (55,56\%), existiendo dos ejemplos entrantes, uno recto y otro indeterminado.

\begin{tabular}{|c|c|c|c|}
\hline \multicolumn{5}{|c|}{ Tratamiento superficial exterior } \\
\hline Bruñido & Raspado & Regularizado & TOTAL \\
\hline 3 & 4 & 200 & 207 \\
\hline \multicolumn{4}{|c|}{ Tratamiento superficie interior } \\
\hline Raspado & Regularizado & No se conserva & TOTAL \\
\hline 9 & 195 & 3 & 207 \\
\hline
\end{tabular}

Tabla 6: Tratamientos superficiales. / Surface treatments.

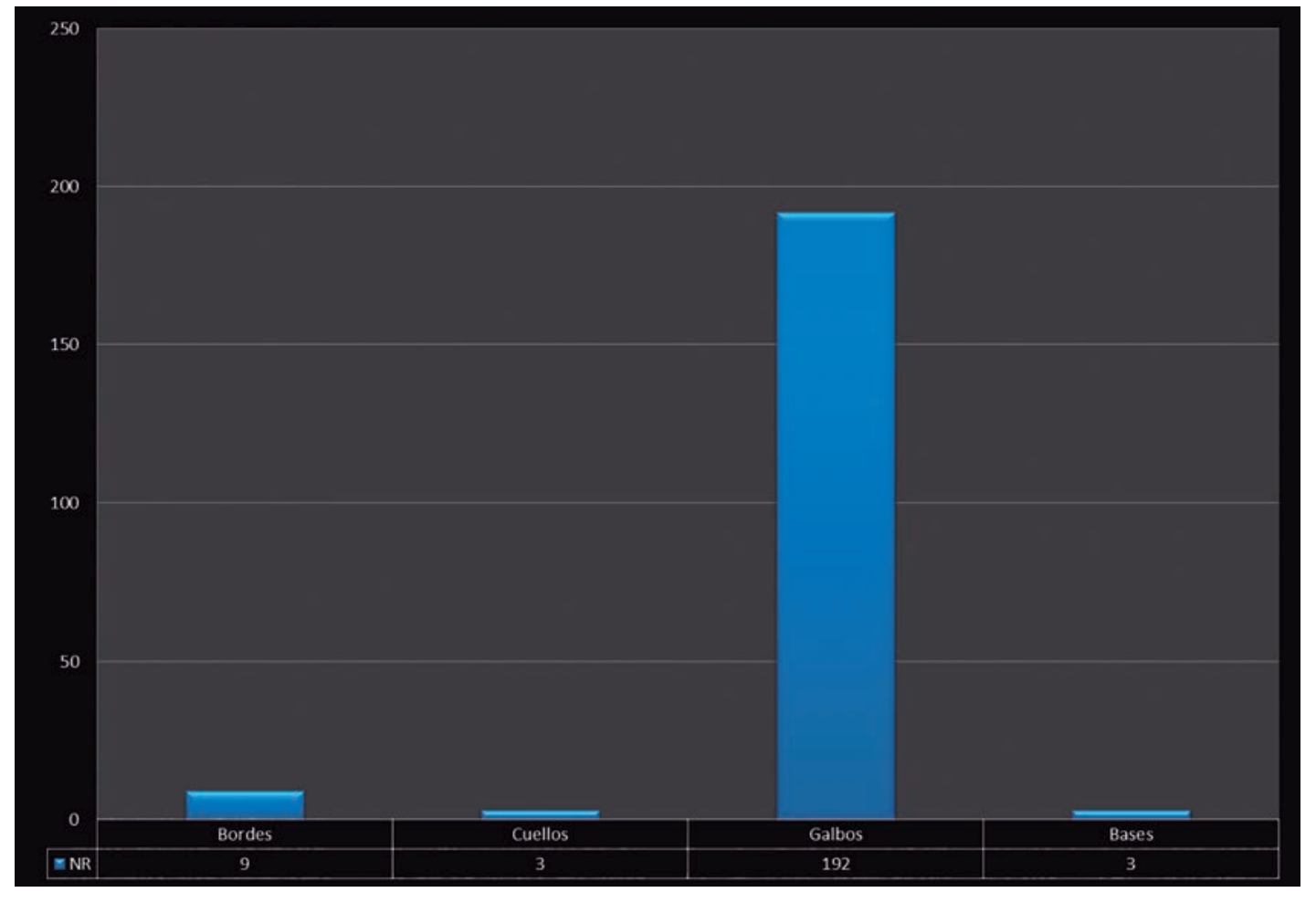

Fig. 8. Partes morfológicas. / Morphological parts of lathe pottery. 
De las tres bases solamente una puede incluirse en el tipo de perfil ondulado con acanaladura inferior, siendo las otras indeterminables.

Un $3,86 \%$ del conjunto $(n=8)$ conserva motivos decorativos. En cinco casos se ha empleado la técnica del pintado con motivos lineales en tres piezas, zoomorfos y vegetales en otro y astrales en la restante (Fig.
9, 4 y 5). La incisión se ha utilizado en tres ocasiones. La más compleja crea retículas en lo que parece ser un galbo reaprovechado, no siendo esta la decoración original de la pieza. Los otros dos ejemplos responden a líneas incisas externas que circundarían la pieza al compás del movimiento del torno. Su aparición no es consecuencia del uso de este ingenio, por lo que pudieron ser realizadas con algún fin como el decorativo.

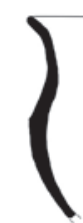

1

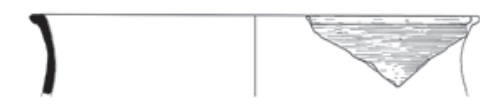

2
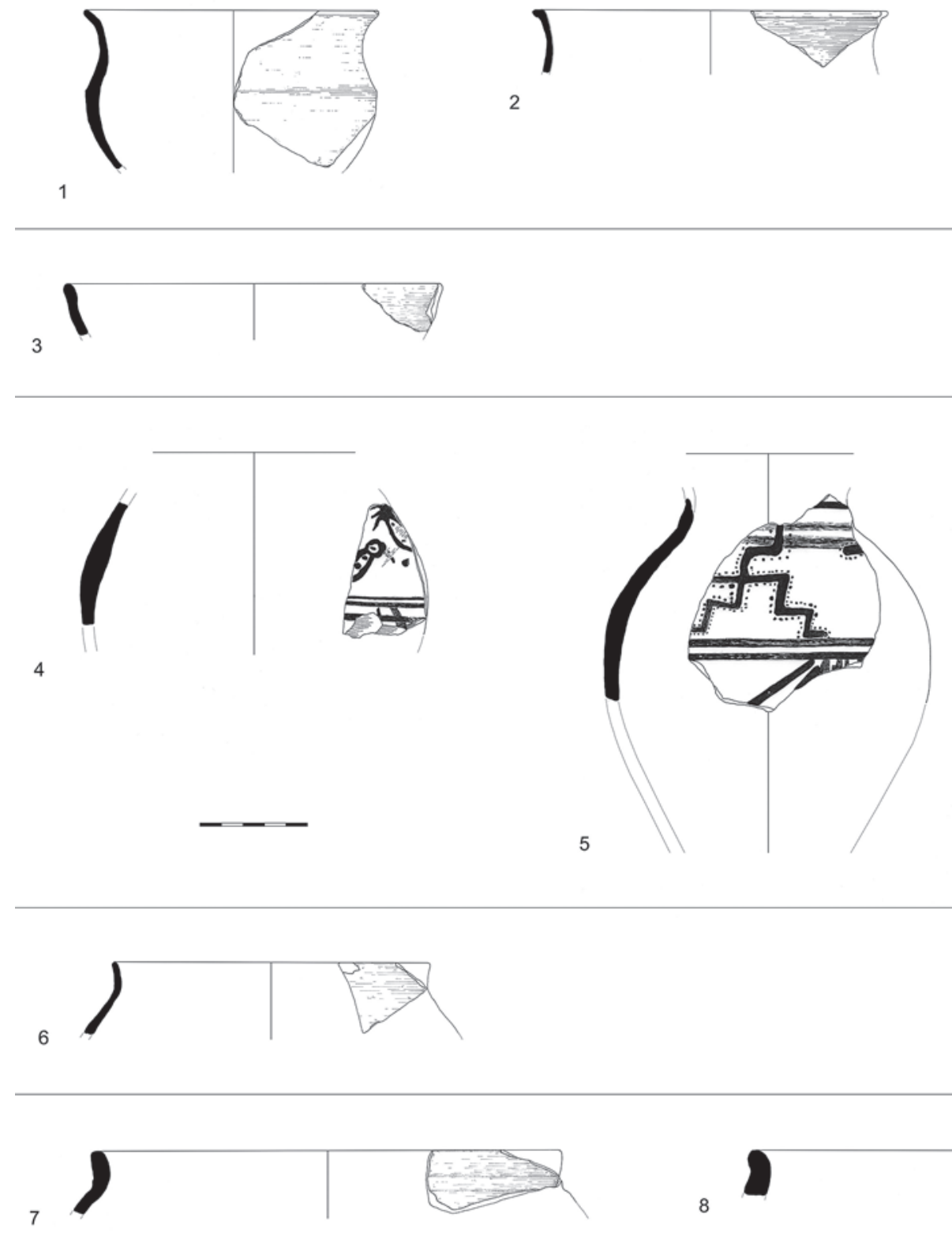

\section{8}

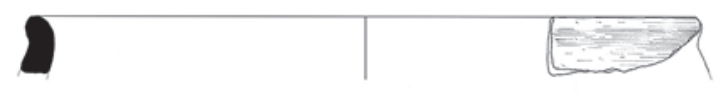

9

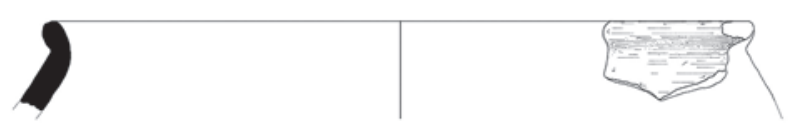

Fig. 9. Formas cerámica a torno de las campañas de 1968-1969. (Dibujos: R. Bolado del Castillo). / Shapes of lathe pottery (Drawing: R. Bolado del Castillo). 
El alto grado de fragmentación continúa siendo elevado, lo que dificulta la reconstrucción de perfiles completos. Solo una pieza, correspondiente con una vasija carenada que carece de base, conserva gran parte del perfil. Las bocas documentadas oscilan entre los $12 \mathrm{~cm}$ y los $25 \mathrm{~cm}$ de diámetro mientras una base alcanza los $18 \mathrm{~cm}$ de diámetro (Tab. 7). Las vasijas son mayoritariamente cerradas.

\begin{tabular}{|l|c|c|c|}
\cline { 2 - 4 } \multicolumn{1}{c|}{} & \multicolumn{3}{c|}{ Diámetros $(\mathbf{c m})$} \\
\cline { 2 - 4 } \multicolumn{1}{c|}{} & Tramo 11-15 & Tramo 16-20 & Tramo 21-25 \\
\hline Boca & 2 & 2 & 3 \\
\hline Base & - & 1 & - \\
\hline
\end{tabular}

Tabla 7: Diámetros de bocas y bases. / Lips and bases diameter.

Podemos distinguir varias formas:

- Vasijas cerradas de labio exvasado y cuerpo carenado con tendencia esférica. Contamos con dos ejemplares, uno de perfil casi completo sin base (Fig. 9, 1) con una boca de $12,8 \mathrm{~cm}$ de diámetro, y un borde de tipo rebordeado al exterior con 17,4 cm de diámetro de boca (Fig. 9, 2).

- Cuencos. Este tipo está representado por un borde redondeado simétrico con una boca de $17,4 \mathrm{~cm}$ de diámetro, que da lugar a una forma abierta de cuerpo hemiesférico (Fig. 9, 3).
- Vasijas de cuerpo ovoidal abierto con decoración pintada. En esta forma hemos agrupado dos galbos de 14 y $15 \mathrm{~cm}$ de diámetro que parecen pertenecer a un mismo tipo de recipiente. El primero de ellos muestra, sobre líneas horizontales, un ave a la izquierda y una posible representación arbórea a la derecha (Fig. 9, 4). El segundo desarrolla una esvástica enmarcada por líneas horizontales, que pudo tener otra escena inferior de la que solo se conservan algunas líneas oblicuas (Fig. 9, 5).

- Vasijas cerradas de cuello exvasado o recto y cuerpo de tendencia esférica u ovoidal. Solamente tenemos un ejemplar compuesto por un borde redondeado simétrico con una boca de $14,8 \mathrm{~cm}$ de diámetro (Fig. 9, 6)

- Vasijas cerradas con engrosamiento bajo el borde. Contamos con dos ejemplares, cuyos bordes son redondeados asimétricos al interior. Uno, de tendencia recta, tiene un diámetro de boca de 22,6 cm (Fig. 9, 7), mientras que el otro, de tendencia entrante, desarrolla un diámetro de boca de 25,6 cm (Fig. 9, 8). Sus dimensiones sugieren que puede tratarse de vasijas o tinajas de almacenaje.

- Vasija cerrada de tendencia exvasada, sin cuello, con marcada transición entre el borde y el cuerpo. La única pieza que responde a estas características se trata de un borde redondeado simétrico con un diámetro de boca de 25,6 cm. Como el grupo anterior, podría formar parte de las vasijas o tinajas de almacenaje (Fig. 10).

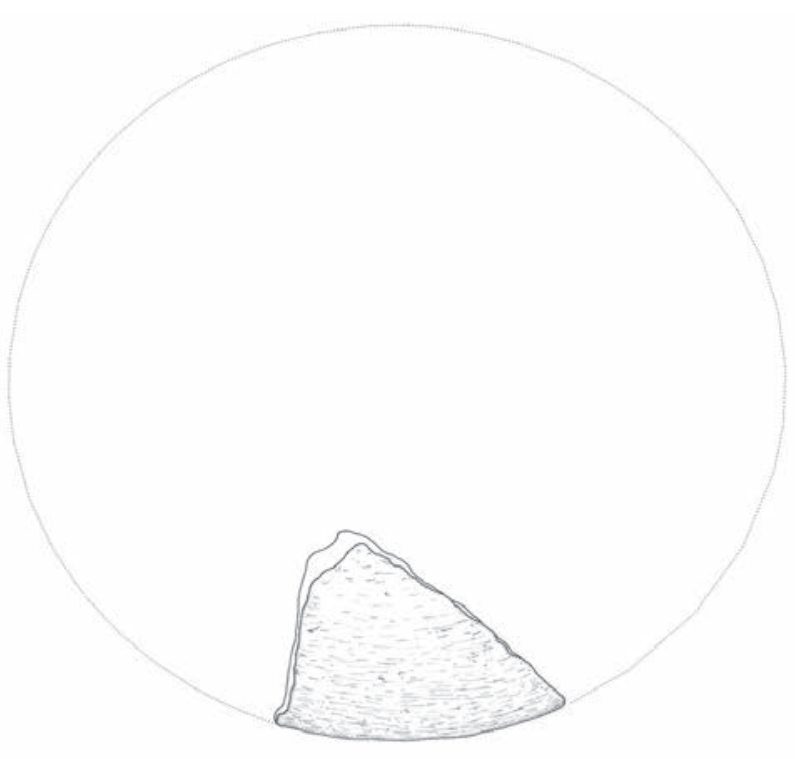

1

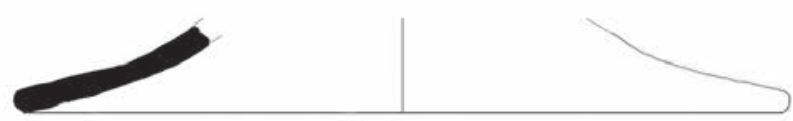

2
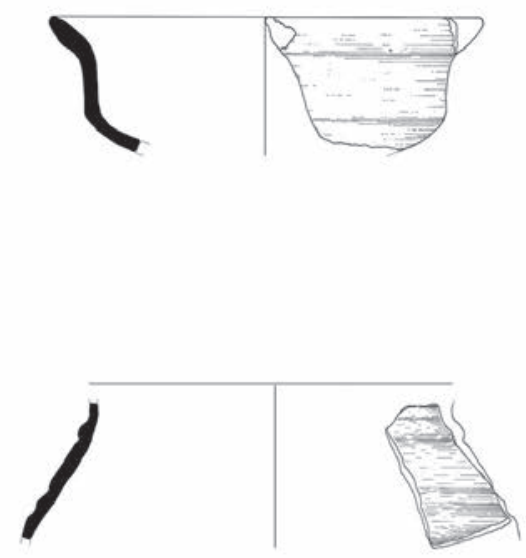

3

Fig. 10. Cerámica campaniense o de imitación. (Dibujos: R. Bolado del Castillo). / Campanian pottery or campanian fake (Drawing: R. Bolado del Castillo). 
La última de las producciones, con un 0,45\% de representatividad dentro de la colección $(n=5)$, es la identificada como cerámica campaniense o de imitación. Está representada por cinco piezas: tres galbos, de los cuales uno conserva rebajes decorativos (Fig. 10, 3), un borde y una tapadera. El borde pertenece a un pequeño vaso de $12 \mathrm{~cm}$ de diámetro de boca que ha sido identificado como parte de la forma Lamboglia B2 (Marcos, 1985: 107), Morel 1222a1 y Beltrán 7 (Aja et al., 1999) y Morel 1221a1 o 1221b1 (Bolado y Fernández Vega, 2010) (Fig. 10, 2). La tapadera, de $25 \mathrm{~cm}$ de diámetro, corresponde a la forma 14 de Lamboglia (Marcos, 1985: 107) (Fig. 10, 1). Todas estas piezas se aproximan a las formas del Campaniense B, fechadas entre el siglo II a.C. y la pri- mera mitad del siglo I a.C. La falta de conservación del barniz en todas las piezas, fruto de su baja calidad, puede suponer la prueba de que estemos ante imitaciones procedentes de los valles del Ebro o del Duero (Mínguez y Sáenz, 2007; Adroher y Caballero, 2012). Una identificación que estaría en consonancia con la ausencia en el poblado de niveles de ocupación romana.

\subsection{Objetos de hierro y bronce}

Entre los 61 restos de hierro solamente una parte ha podido ser identificada. Relacionados con el armamento encontramos el extremo distal de una punta de lanza (Fig. 11, 1) y cuatro fragmentos de regatón (Fig.
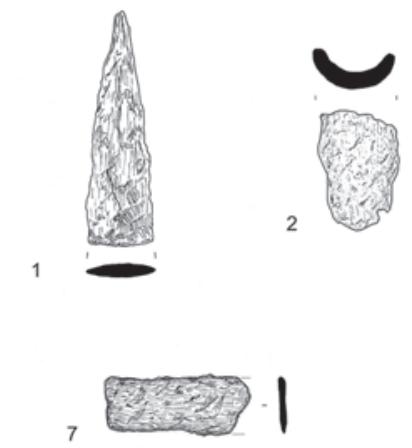

8
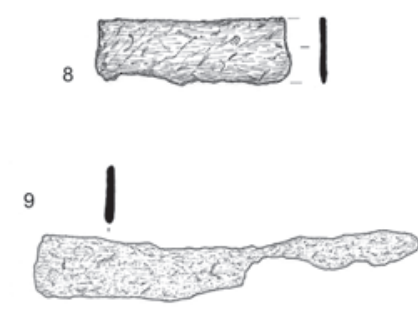

10
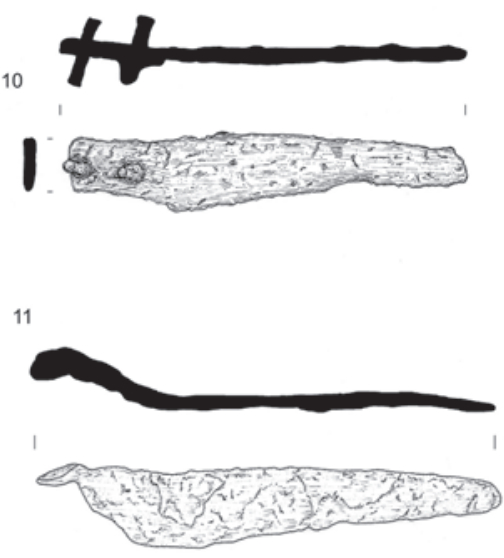
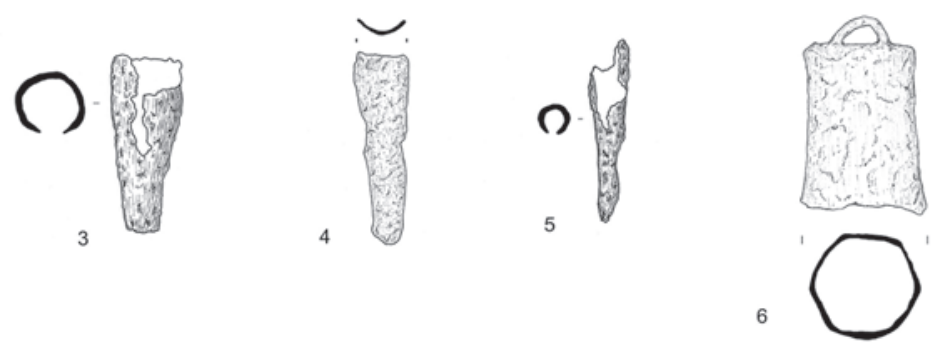

12
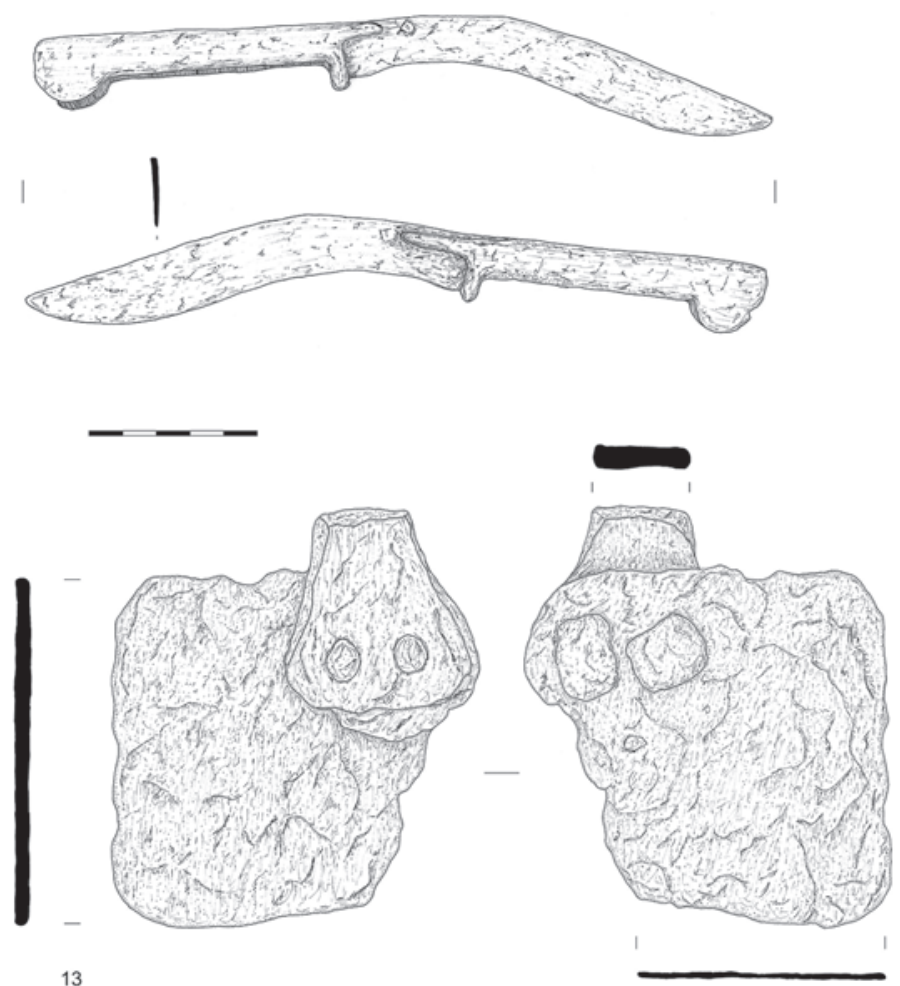

Fig. 11. Objetos de hierro de las campañas de 1968-1969. (Dibujos: R. Bolado del Castillo). / Iron objects of 1968-1969 (Drawing: R. Bolado del Castillo). 
11, 2 a 5). Resultan frecuentes los cuchillos, documentándose siete fragmentos de hoja de desarrollo recto (Fig. 11, 7 a 9). Dos, de hoja de tendencia recta, se fabricaron para enmangues orgánicos con una fijación mediante remaches (Fig. 11, 10) o en espiga (Fig. 11, 11). El mejor conservado fue creado íntegramente en hierro, contando con una hoja afalcatada que se uniría al mango con remaches. Este estaría conformado por dos cachas y una pieza orgánica situada entre ambas que, a su vez, ayudaría a fijar la hoja (Fig. 11, 12). Otros objetos a destacar son un campano (Fig. 11, 6), una azada de hierro (Fig. 11, 13) y media fíbula de aro sin

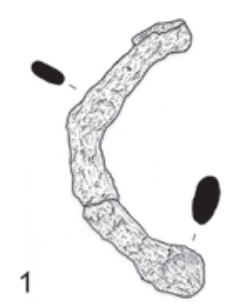

5
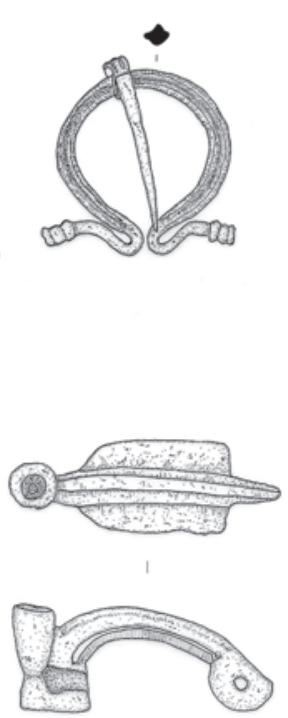

10

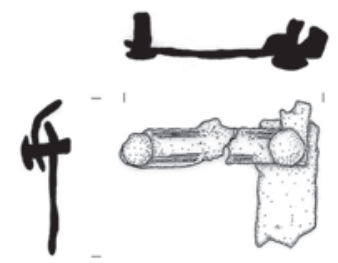

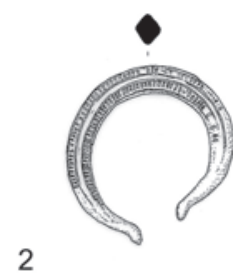

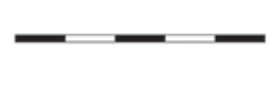

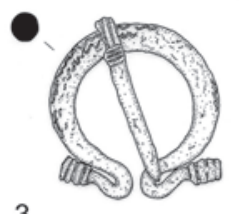

3

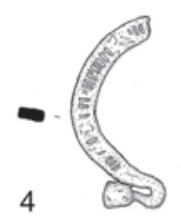

6

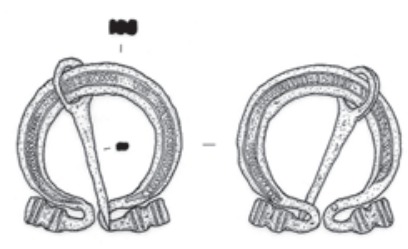

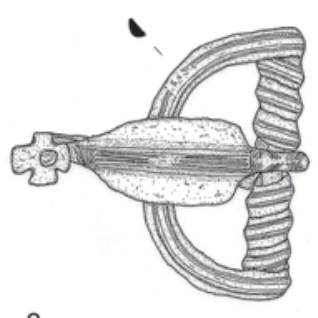

8

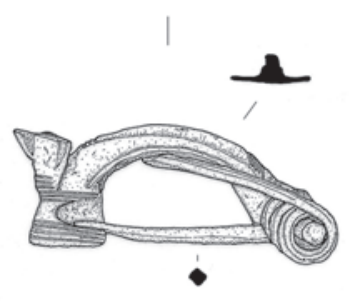

9

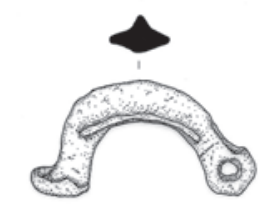

Fig. 12. Fíbulas y elementos de bronce de las campañas de 1968-1969. (Dibujos: R. Bolado del Castillo). / Fibulas and bronze objects of 1968-1969 (Drawing: R. Bolado del Castillo).
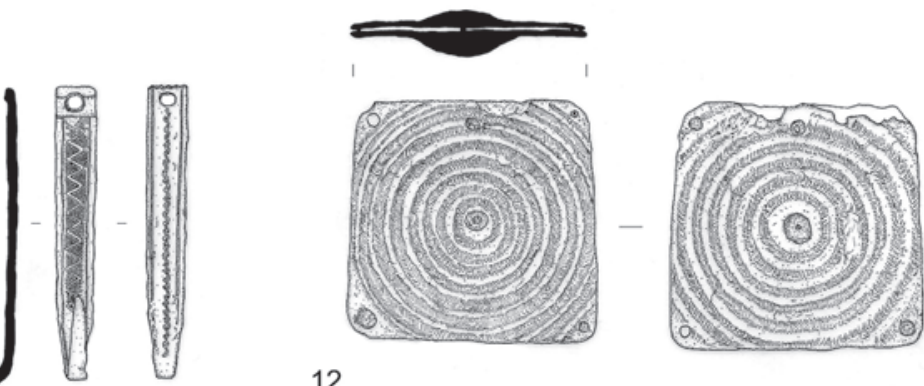
resorte "omega" que conserva parte del puente, incluyéndose de forma genérica en el tipo 35 de Erice (1995: 207-225) y 21 de Mariné (2001: 258-272) (Fig. 12, 1).

Dentro de las piezas de bronce destaca el grupo de ocho fíbulas, cinco de aro sin resorte "omega" y tres del tipo La Tène o de apéndice caudal. Entre las primeras tenemos un puente con decoración en ambas caras de líneas paralelas incluido en el tipo 21.2.b3 de Mariné (Fig. 12, 2); tres fíbulas completas, una con decoración de bandas de "SSS" en el puente, pertenecientes a los tipos 35.1.a.2 de Erice o 21.2.b.1 de Mariné (Fig. 12, 3), 35.1.c de Erice o 21.2.a.2 de Mariné (Fig. 12, 6) y 35.1.d de Erice o 21.2.b6 de Mariné (Fig. 12, 5); y medio puente con decoración de líneas verticales paralelas que forma parte del tipo 35.1.c de Erice o 21.2.a.2 de Mariné (Erice, 1995: 207-225; Mariné, 2001: 258-272) (Fig. 12, 4).

Las fíbulas de La Tène o de apéndice caudal están representadas por un puente con prolongación soldada de tipo torre circular en cuya parte superior existe un hueco que pudo acoger algún remate decorativo (Fig. $12,7)$, y un ejemplar completo con aguja, resorte y prolongación soldada al puente de tipo torre con cuatro escotaduras (Fig. 12, 8); ambas piezas forman parte del tipo 8A2 de Argente (1994: 88). El tercer ejemplar está compuesto por un puente con la prolongación desaparecida, lo que solo nos permite incluirlo en el grupo $8 \mathrm{~A}$ de Argente (1994: 84-95) (Fig. 12, 9).

A todo ello debemos sumar una pieza de bronce que pudiera vincularse con la abrazadera de una vaina de puñal (Fig. 12, 10), diversos elementos de guarnicionería, una cadena, una aguja, una pieza formada por dos placas cuadradas de 4,9 x 4,5 cm con decoración troquelada a base de círculos concéntricos y remaches en los extremos de funcionalidad desconocida (Fig. 12, 12), y una pieza identificada con un colgante que, a pesar de sus dimensiones, invita a relacionarla con un enganche de tahalí o con la pieza macho de algún otro sistema de enganche (García Guinea y Rincón, 1970: 15) (Fig. 12, 11).

\subsection{Restos humanos}

En la Cata Tierra Julia el equipo de García Guinea y Rincón (1970) halló los restos de un cráneo formado por un fragmento de esplacnocráneo: el maxilar superior derecho y la región orbitaria derecha, así como la pared lateral derecha de la órbita y fosa nasal izquierdas, en continuidad con el hueso frontal y esfenoides derecho (Fig. 13, A). Presenta una importante reconstrucción realizada tras su recuperación, que afecta al hueso cigomático y a la región superior del maxilar. Conserva in situ dos piezas dentales (hemiarcada superior derecha). En la región frontal derecha presenta una solución de continuidad irregular, de eje mayor ligeramente oblicuo a la órbita (Fig. 13, B). Dicha lesión atraviesa todo el espesor del hueso, siendo visible por la cara interna donde también se aprecian otras tres lesiones que afectan únicamente a la tabla interna del hueso (Fig. 13, C).
Las características craneales, reborde orbitario de grado 2 y glabela de grado 1-2 (Acsadi \& Nemeskeri, 1970), escaso relieve de las crotáfites (punto de inserción de músculo temporal) y verticalidad frontal, orientan hacia el sexo femenino del individuo.

La determinación de la edad se ha realizado mediante el estudio del desgaste dental y el cierre de las suturas craneales, aunque con grandes limitaciones: sólo conserva dos piezas dentales, el segundo premolar y primer molar derechos, y parte de la sutura coronal en su vertiente derecha, así como la sutura esfenofrontal derecha, que se encuentra alterada por el proceso de restauración. Según la clasificación de Brothwell (1965) para la determinación del grupo etario de poblaciones antiguas en base al desgaste dental, podríamos incluirlo en el grupo de entre 35-45 años de edad. En cuanto al estudio de las suturas, la sutura coronal presenta un cierre significativo, salvo en la sección media, y se encuentra completamente fusionada a nivel de cara interna. La sutura esfenofrontal parece completamente cerrada. Todo ello indica que se trata de un individuo adulto maduro.

Presenta una apertura nasal media y unas órbitas anchas, según las medidas de las órbitas y la cavidad nasal (Tab. 8). La escasez de datos impide realizar comparativas con grupos ancestrales concretos.

\begin{tabular}{|l|c|c|}
\cline { 2 - 3 } \multicolumn{1}{c|}{} & Órbita & Nariz \\
\hline Altura & 29,5 & 43 \\
\hline Anchura & 37 & 21 \\
\hline Índice & 79,73 (chamaeconco) & 48,84 (mesorrino) \\
\hline
\end{tabular}

Tabla 8: Datos antropométricos (en mm). / Anthropometric data (mm).

Desde el punto de vista patológico, presenta una lesión redondeada, hiperostótica, de unos $3 \mathrm{~cm}$ de diámetro y escaso relieve localizado en la región central del hueso frontal, justo por encima de la glabela. Es compatible con un osteoma (Fig. 13, D).

Los osteomas son tumores benignos, abultamientos redondos u ovalados, sésiles y sólidos, que se proyectan desde la superficie subperiósticas o endóstica de la cortical del hueso; los subperiósticos se originan frecuentemente sobre o dentro del cráneo o el esqueleto facial. Son de crecimiento lento y suelen detectarse en adultos de mediana edad, sin que lleguen a producir clínica a menos que obstruyan cavidades sinusales o compriman estructuras nerviosas (Robbins y Cotran, 2007). En paleopatología, los osteomas son los tumores benignos más descritos (Campillo, 1993).

Las lesiones más llamativas que presenta esta pieza son de tipo traumático. En la región frontal derecha existe una solución de continuidad de forma irregularmente alargada, de $32 \mathrm{~mm}$ de longitud máxima y 19 mm de anchura máxima (Fig. 14, A). La identificaremos como lesión "A". A nivel externo (ectocráneo o tabal ex- 


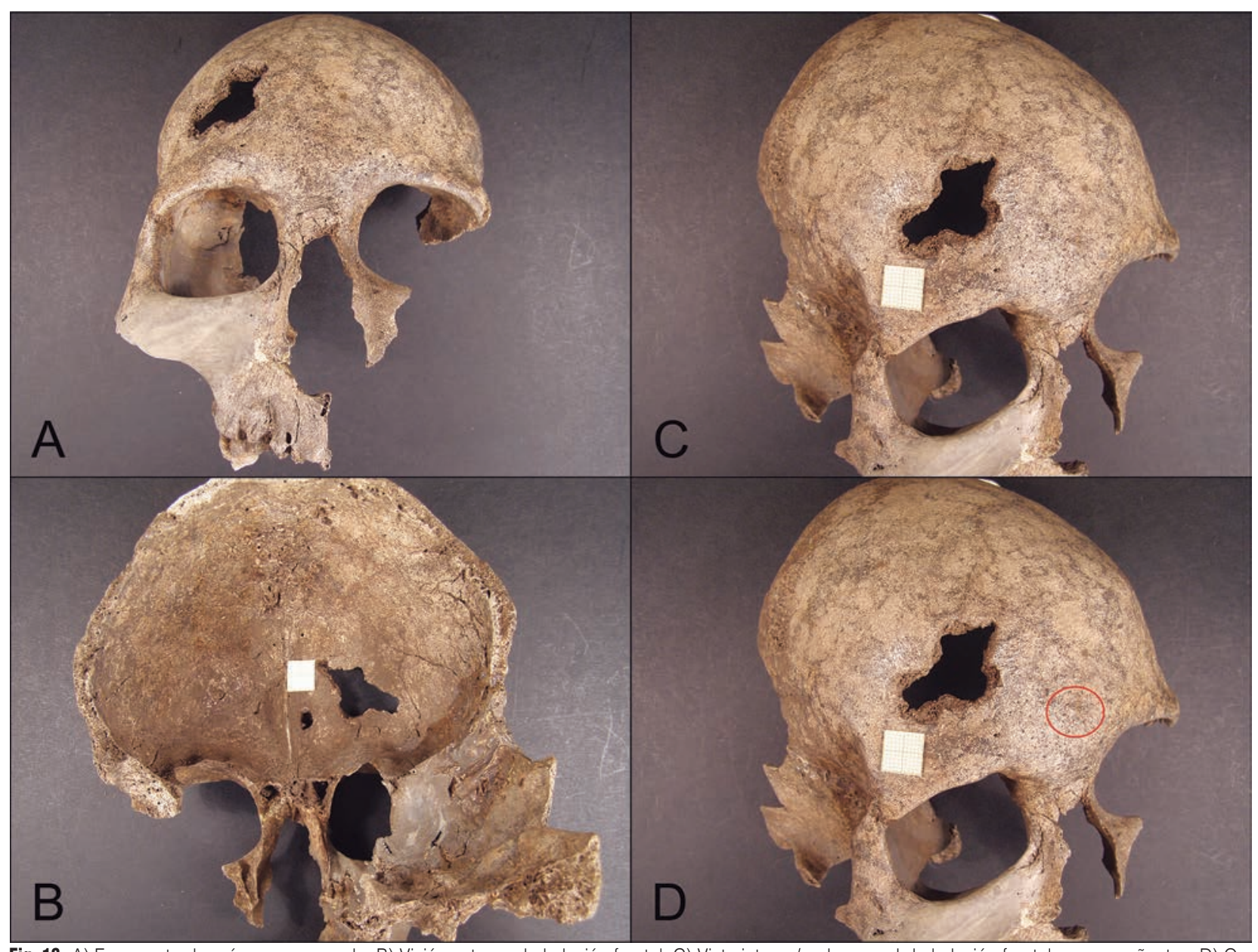

Fig. 13. A) Fragmento de cráneo conservado; B) Visión externa de la lesión frontal; C) Vista interna/endocraneal de la lesión frontal y acompañantes; D) Osteoma. ( A) Preserved skull fragment; B) External view of the frontal injurie; C) Interna view/endocranial of the frontal injurie and nearby injuries; D) Osteoma.

terna), presenta unos bordes irregulares y de perfil suave, probablemente debido a alteraciones tafonómicas (roce con el terreno). En la tabla interna (endocráneo) las dimensiones son ligeramente inferiores, 29,1 mm de longitud y $18,7 \mathrm{~mm}$ de anchura, y los bordes son más nítidos y abruptos. A nivel endocraneal también se identifican otras 3 lesiones romboidales (lesiones "B") que se corresponden con fracturas -hundimientos de la tabla interna del hueso, sin que se llegue a formar una solución de continuidad con la tabla externa. Se sitúan a ambos lados de la crista galli, dos de ellas a nivel frontal izquierdo y otra en el derecho, bajo la lesión A. Las dos lesiones del frontal izquierdo mantienen el fragmento de tabla interna in situ, alojado en diploe. (Fig. 14, B). Todas las lesiones presentan una coloración similar al resto del hueso produciéndose en el hueso fresco, cuando aún conservaba sus propiedades viscoelásticas, por lo que descartamos el origen en el momento de la excavación o recuperación. Ninguna presenta signos de regeneración ósea, lo que descarta la supervivencia del individuo a estas lesiones. Por lo tanto, nos encontramos con unas lesiones perimortales, producidas en el momento próximo a la muerte del individuo, sin poder precisar si fueron la causa de su muerte o si se produjeron inmediatamente después de la misma.

Es evidente que las lesiones B fueron realizadas desde una dirección posterior dada su localización endocraneal. En cuanto a la lesión A, presenta unas dimensiones mayores en la tabla externa que en la interna, es decir, tiene forma troncocónica, o de embudo, con la base localizada en la tabla externa. Desde un punto de vista forense, las lesiones producidas en los huesos planos presentan un diámetro menor en el orificio de entrada que en el de salida, por lo que podemos deducir que también se produjo desde la parte posterior de la cabeza y se correspondería con el orificio de salida de una lesión producida por un objeto penetrante, cuyo orificio de entrada se encontraría, presumiblemente, en la región occipital de cráneo.

La lesión A presenta un borde agudo y otro aparentemente romo, visibles tanto en la tabla externa (Fig. 14, C) como en la interna (Fig. 14, D).

Esta morfología es compatible con una herida inciso-contusa producida por un objeto de un solo filo, según la terminología forense. Las lesiones semicirculares 


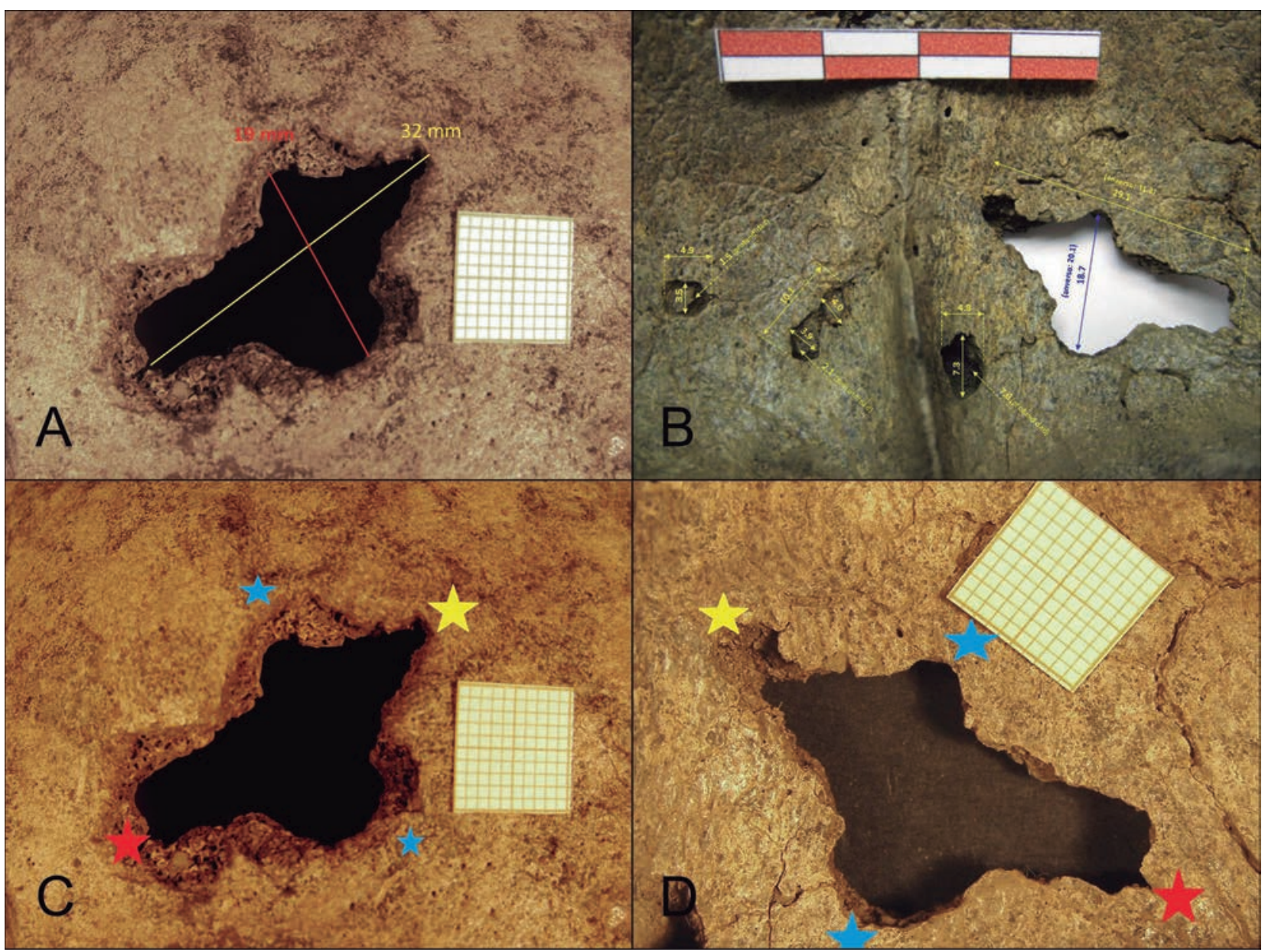

Fig. 14. A) Dimensiones de la lesión A en la tabla externa del cráneo; B) dimensiones de lesión A y lesiones B en tabla interna del cráneo; C) Vista externa de la lesión A (asterisco amarillo: borde agudo; asterisco rojo: borde romo; asterisco azul: lesiones semicirculares); D) Vista interna de la lesión A (asterisco amarillo: borde agudo; asterisco rojo: borde romo; asterisco azul: lesiones semicirculares). / A) Dimesions of the injurie A on the external table of the skull; B) Dimensions of injurie A and injuries B on the internal table of the skull; C) External view of the injurie A (yellow asterisk: sharp edge; red asterisk: blunt edge; blue asterisk: semicircular injuries); D) Internal view of the injurie A ((yellow asterisk: sharp edge; red asterisk: blunt edge; blue asterisk: semicircular injuries).

a nivel central de la misma orientan hacia un objeto con una nervadura central. Teniendo en cuenta la época a la que pertenece el cráneo, y dado que la morfología de la lesión no es compatible con ningún utensilio de uso agrícola o similar, entendemos que el objeto causante debe pertenecer a la panoplia militar del momento. De todas las armas usadas, una lanza es la única arma compatible con la lesión descrita.

Si bien es cierto que una lanza es un arma de doble filo y las dos lesiones semicirculares no presentan el mismo eje central, no hemos encontrado ningún otro objeto que pudiera producirla. $Y$ entendemos que la ausencia de todos los elementos característicos de lesiones producidas por objetos de doble filo se deba a alteraciones tafonómicas. Por otro lado, parece muy poco probable que dos objetos diferentes actuasen en esa misma región, produciendo esta única lesión.

En el caso de las lesiones B se realiza el diagnóstico diferencial entre lesiones producidas por carnívoros, dadas sus dimensiones, o lesiones producidas por arma punzante, que podría corresponder con la parte más distal de una lanza, ya que a ese nivel la sección de la misma suele ser romboidal.

Las distancias entre las tres lesiones no son similares ni constantes (Fig. 15); en cuanto a la morfología, las lesiones producidas por carnívoros suelen ser más redondeadas y con un hundimiento sutil de la cortical. En nuestro caso, la tabla interna se encuentra totalmente hundida, con una fragmentación en bloque, o simplemente ha desaparecido por completo. Si comparamos las dimensiones de los propios orificios con las dimensiones de los colmillos de los carnívoros más habituales (Camarós et al., 2015), vemos que los orificios del cráneo son mayores, tanto en el eje mayor (4,9 $\mathrm{mm}, 10,1 \mathrm{~mm}$ y $7,3 \mathrm{~mm}$ ) como en el menor (3,5 mm, 4 $\mathrm{mm}$ y $4,8 \mathrm{~mm})$.

Tampoco la localización de las lesiones es la más habitual en lesiones tafonómicas producidas por carnívoros, ya que suelen elegir huesos ricos en médula, siendo el cráneo uno de los menos atractivos. En 


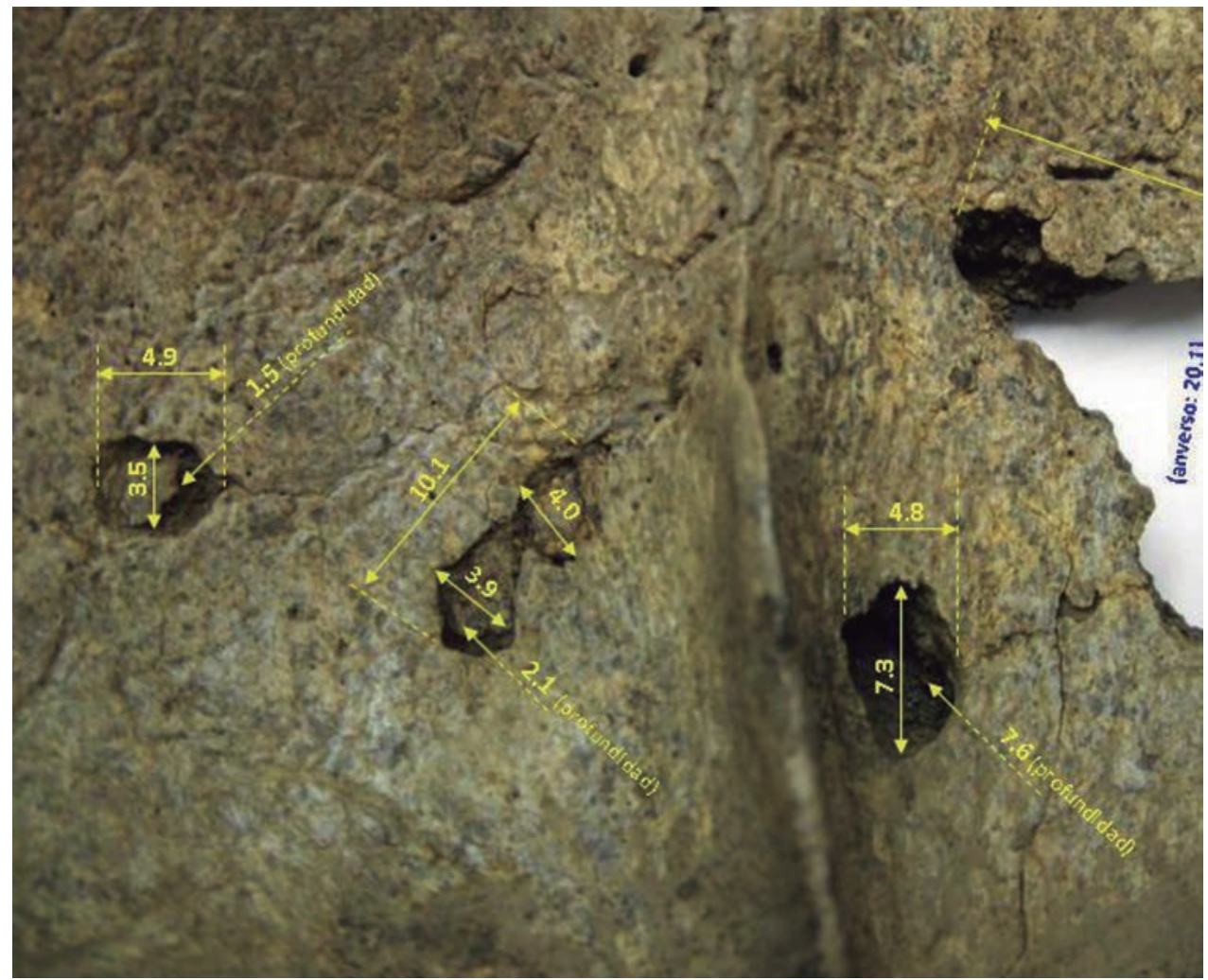

Fig. 15. Detalle de las lesiones identificadas como B. / Detail of the injuries $\mathrm{B}$. el caso de producirse en el cráneo, suelen localizarse en la cara externa, siendo muy raras las lesiones endocraneales (Bright, 2011). Por todo ello descartamos el origen tafonómico animal de las lesiones.
El cráneo ha sido datado en 2285 \30 BP (Poz-40283) cuya calibración a dos sigma, con un 0,9\% de probabilidad lo sitúa entre el 219 y el 213 cal BC, con un $29 \%$ de probabilidad entre el 295 y el 229 cal BC y, con un 65,5\% de probabilidad, entre el 405 y el 352 cal BC $^{1}$ (Fig. 16).

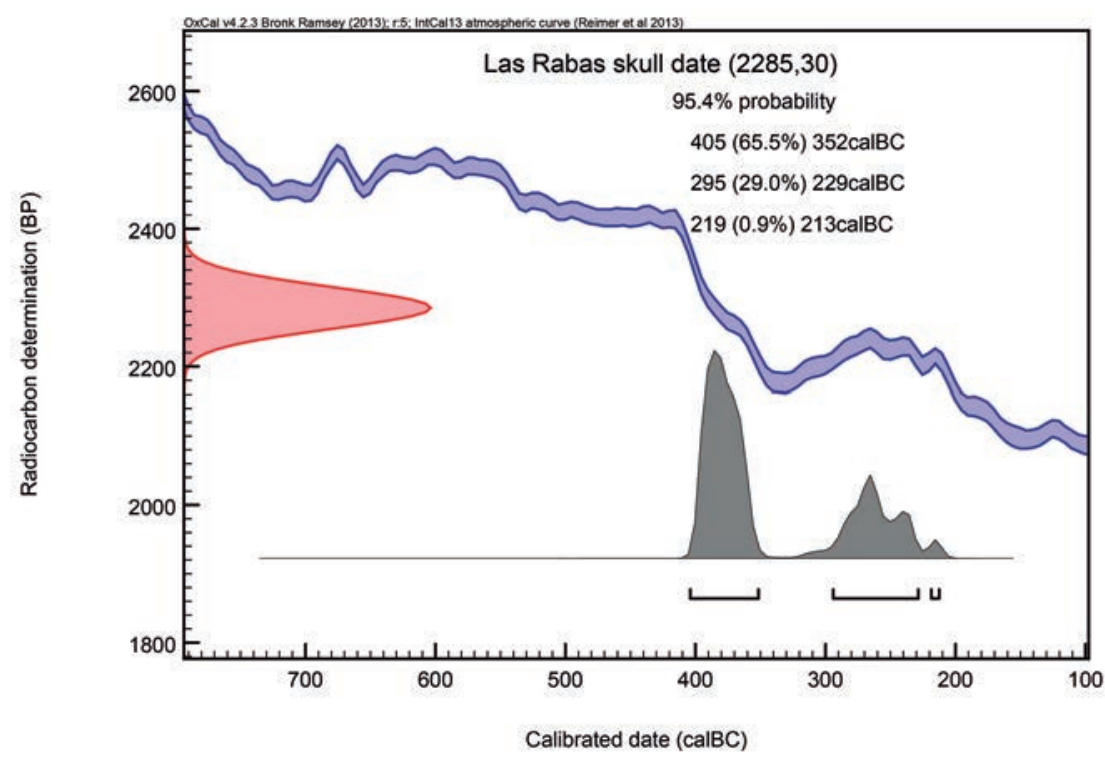

Fig. 16. Datación del cráneo del castro de Las Rabas. / Dating of the skull of the hillfort of Las Rabas.

\footnotetext{
${ }^{1}$ La calibración se ha realizado con el programa OxCal 4.3 (Bronk, 2001, 2009) empleando la curva de calibración IntCal13 (Reimer et al., 2013)
} 


\subsection{Otros materiales}

Otros materiales a destacar dentro del registro antiguo son los restos de asta, entre los que encontramos partes distales de posibles mangos con perforación (Fig. 17, 1 a 3), dos fragmentos de mango, uno de ellos con líneas incisas posiblemente decorativas (Fig. 17, 4 y 5), un candil trabajado con abertura longitudinal (Fig. $17,6)$, dos candiles de ciervo con ranura en el extremo distal que pudieran haber sido destinados para mangos (Fig. 17, 7 y 8), y una pieza elipsoidal con los extremos rectos y una de sus caras planas, que pudo ser empleada como espátula (Fig. 17, 9).
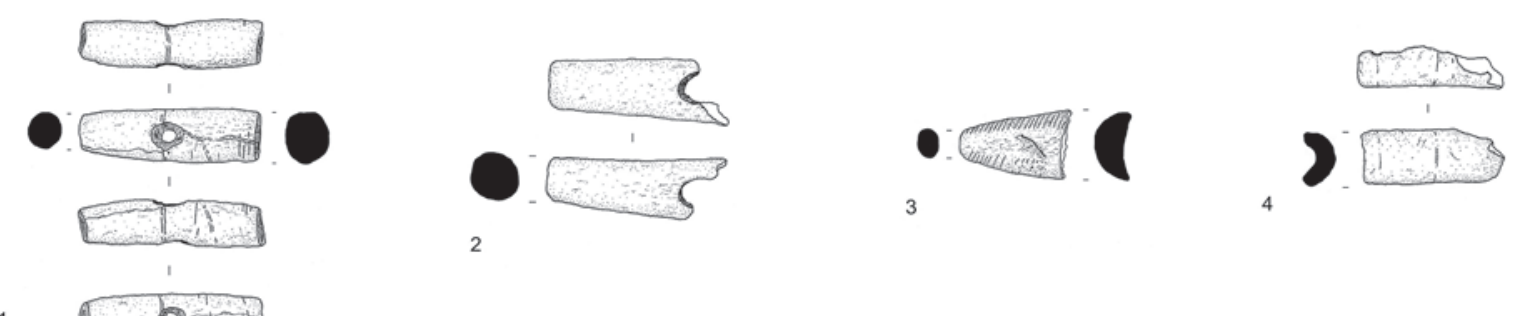

1

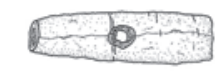

3
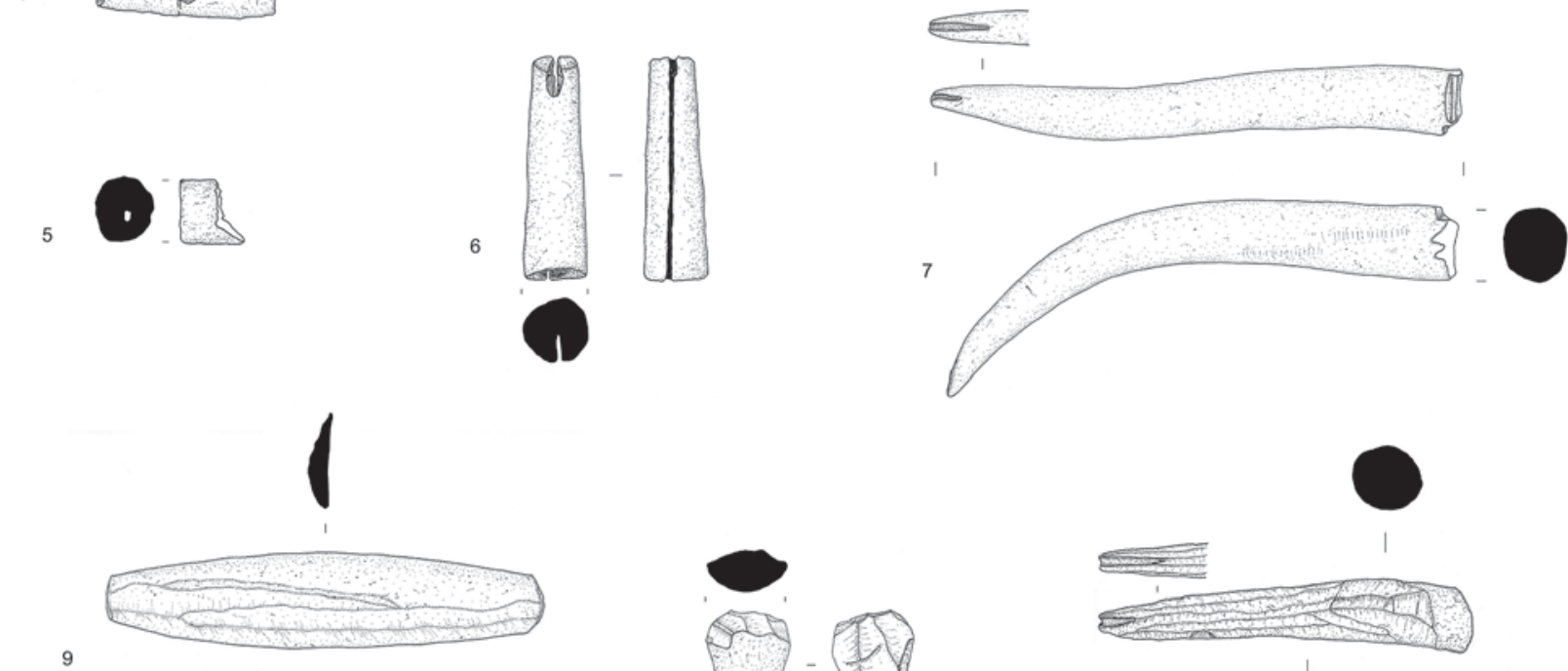

9

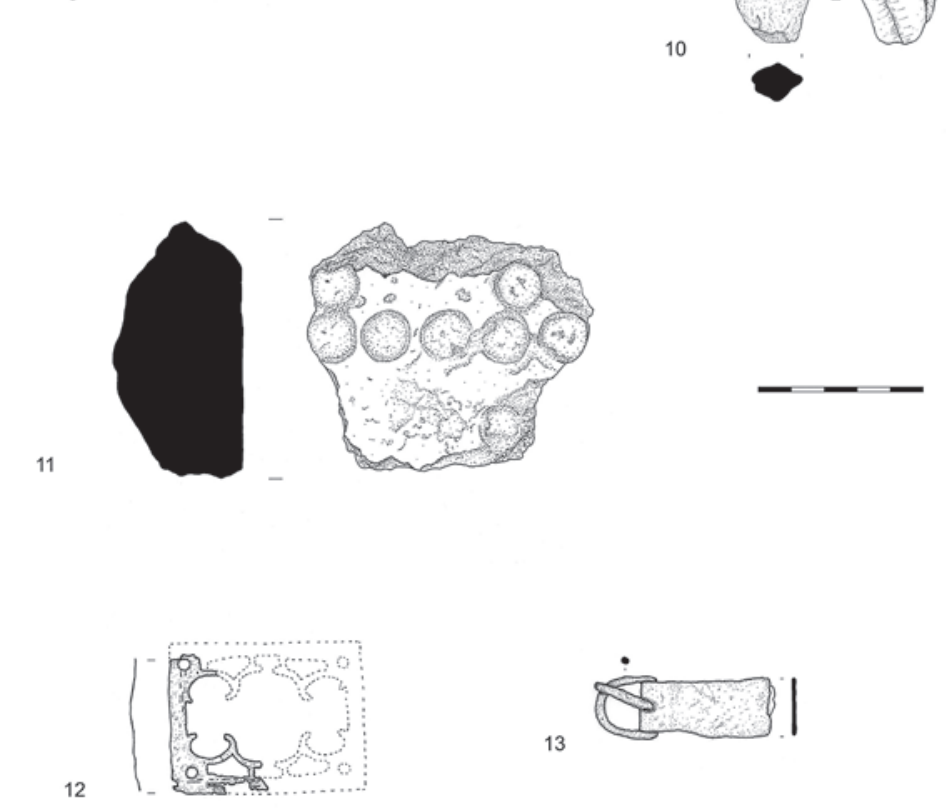

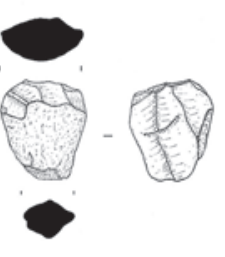
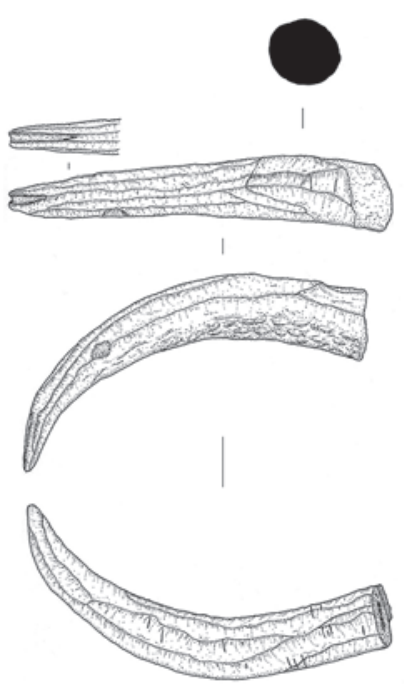

14

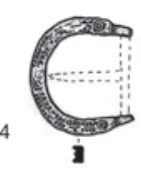

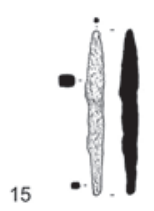

15

Fig. 17. Restos de asta, conglomerado de pared, raspador y material militar romano. (Dibujos: R. Bolado del Castillo). / Poles, fragment of wall with decoration, scraper and roman military equipment (Drawing: R. Bolado del Castillo). 
Son de señalar igualmente dos monedas de bronce inidentificables con módulos de 27,7 y $27 \mathrm{~mm}$ y un peso de 8,6 y 7,3 gr.; un fragmento de conglomerado de cabaña con decoración a base de círculos impresos (Fig. 17, 11) y un raspador de sílex (Fig. 17, 10).

\subsection{Material romano}

Dentro del registro existen cuatro piezas vinculadas con el mundo militar romano que ya han sido estudiadas con anterioridad: una placa calada de balteus (Fig. 17, 12) (Fernández Ibáñez, 2006: 261 y 263, fig.2,5; Bolado et al, 2010: 90-91), una hebilla en D con pasador y chapa (Fig. 17, 13) (Bolado et al, 2010: 90-91), el puente de una hebilla en "D" decorada con círculos concéntricos en los extremos y su parte media, y dos bandas de círculos en altorrelieve que transcurren paralelas por el puente (Fig. 17, 14) (Bolado et al., 2008: 90-91), y una punta de flecha de tipo sirio, un modelo frecuentemente usado durante las Guerras Cántabras (Fig. 17, 15) (Peralta, 2007: 497-500; Torre et al., 2013: 65-66).

\section{LA INTERVENCIÓN ARQUEOLÓGICA DE 2011: EL SONDEO 1/2011}

El Sondeo 1 se replanteó en la zona septentrional de la vaguada, próximo al área ocupada por las antiguas catas (Fig. 1), documentándose durante su excavación un total de seis unidades estratigráficas (Fig. 18):
- U.E.1: capa vegetal.

- U.E.2: unidad compacta de tierra negruzca mezclada con piedras de tamaño pequeño y mediano.

- U.E.3: nivel compacto de piedras medianas y pequeñas con escasa tierra.

- U.E.4: unidad de tierra negruzca suelta con escasa piedra.

- U.E.5: nivel plástico de tierras marrones.

- U.E.6: roca madre

Ninguna de ellas ha aportado estructura alguna, proporcionando materiales contemporáneos entre sí desde la U.E.1 a la U.E. 4. En total se han recuperado 2904 piezas: 2271 óseas, 396 de cerámica a torno, 166 de cerámica a mano, 24 bronces, 30 piezas de hierro, tres restos de fíbula, dos materiales romanos y 12 piezas de otros materiales (Fig. 19).

La U.E.4 destaca por proporcionar casi el 77\% del material, lo que nos permite considerarla como el nivel original. La U.E. 2 y 3 seguramente respondan a los niveles artificiales de aterrazamiento agrícola, los cuales fueron realizados con el aporte de tierras de las proximidades, explicándose así el escaso material proporcionado. Esta propuesta estratigráfica aconseja el estudio conjunto, no por U.E., del registro. La metodología empleada ha sido la misma referida en el apartado anterior, separándose nuevamente los objetos de adscripción romana en subapartado independiente.
N

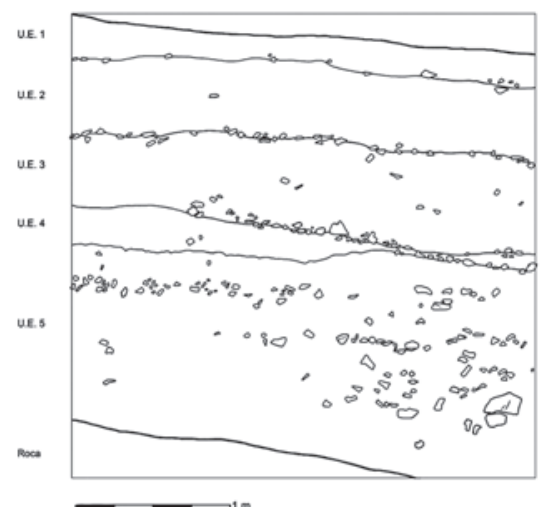

$\mathrm{S}$

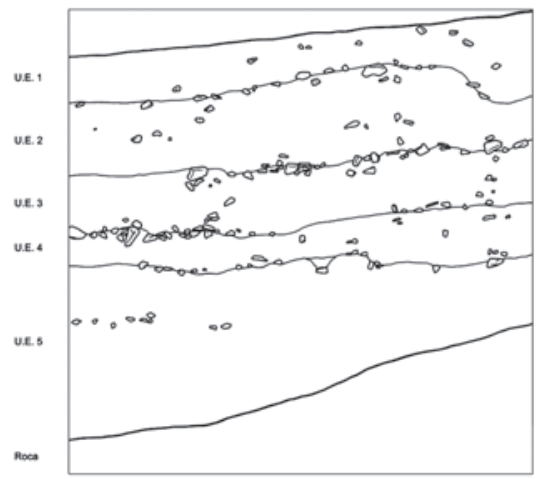

E

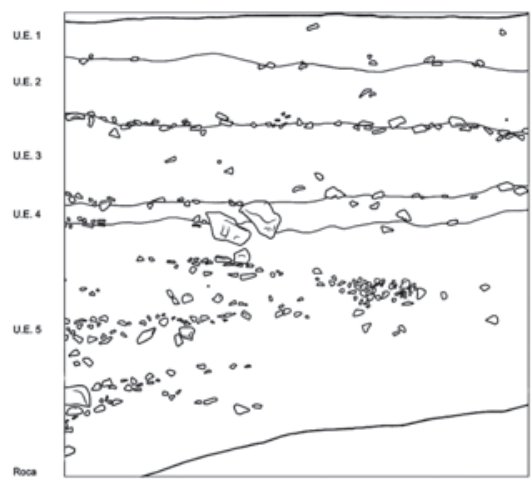

w

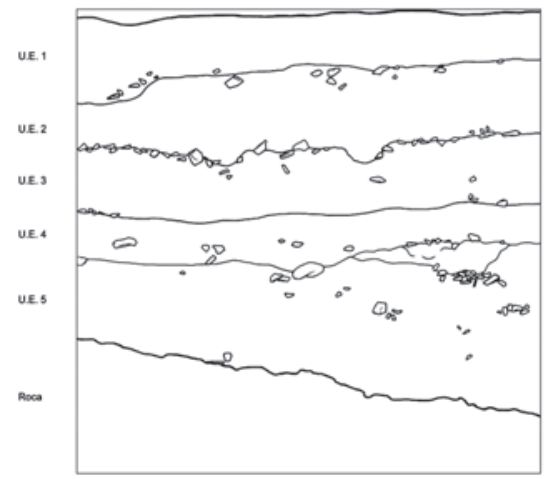

Fig. 18. Estratigrafía del Sondeo 1. / Stratigraphy of the trial excavation of 2011 


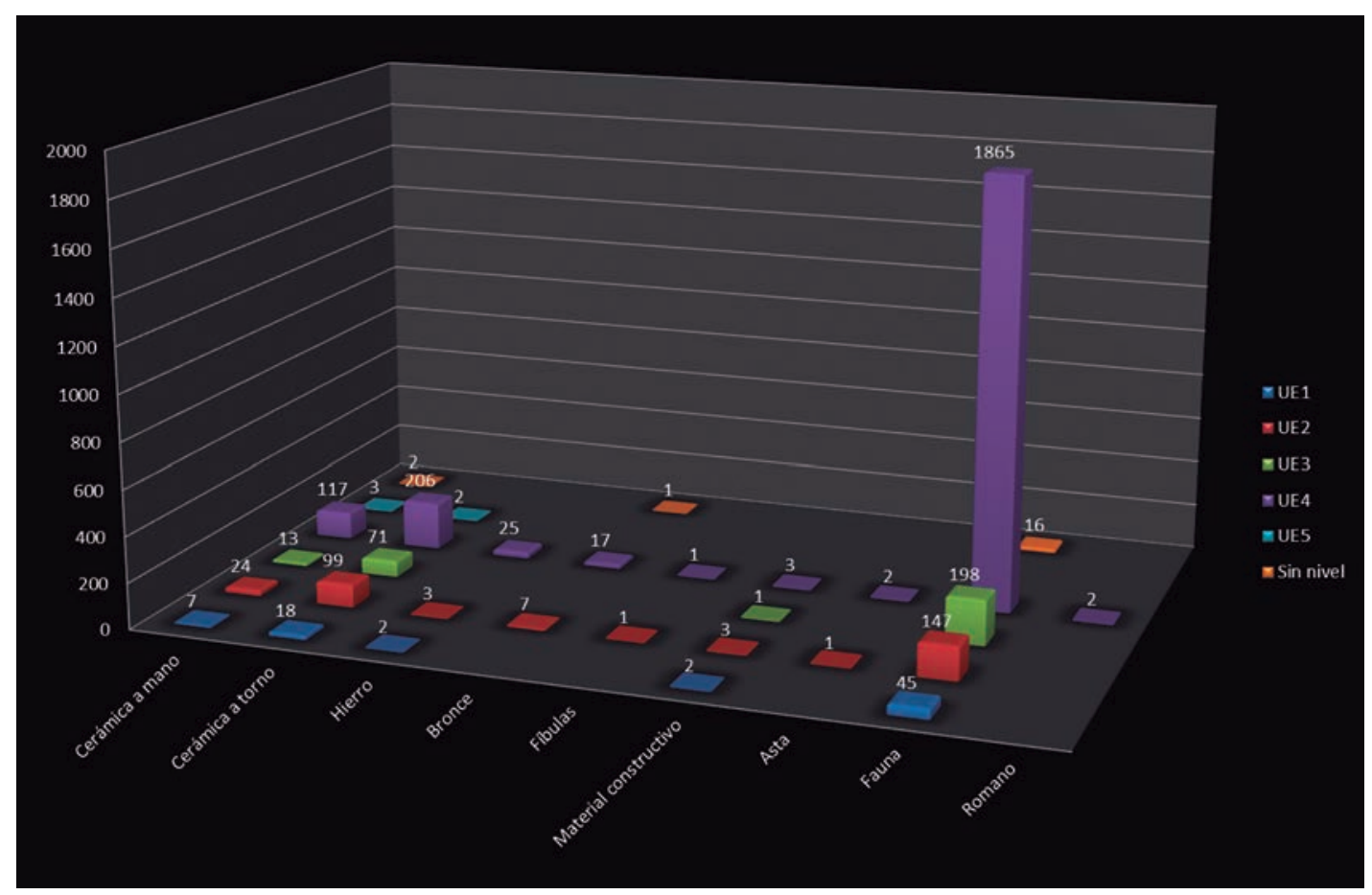

Fig. 19. Distribución de materiales por U.E. / Archaeological material distribution by U.E.

\subsection{La producción cerámica}

La producción cerámica supone el 26,84\% del registro material, dividiéndose entre cerámica a mano y cerámica a torno. La cerámica a mano está representada por 166 fragmentos, de los cuales siete proceden de la U.E. 1, 24 de la U.E.2, 13 de la U.E.3, 117 de la U.E.4, tres de la U.E.5 y dos están descontextualizados. A nivel tecnológico los 17 bordes conservados muestran un grosor medio de $7,23 \pm 4,99 \mathrm{~mm}$ y las ocho bases de $7,28 \pm 2,13 \mathrm{~mm}$ (Tab. 9). La factura manual ha dejado trazas en todos los fragmentos los cuales, en el 83,73\% de los casos, han sido cocidos en atmósferas reductoras, mientras que el 16,27\% restante es producto de cocciones oxidantes. Salvo 11 superficies exteriores y diez interiores, el resto han sido tratadas. Predomina el regularizado, que se documenta en el $84,34 \%$ de las superficies exteriores y en el 90,36\% de las interiores. El raspado aparece en el 7,83\% de las superficies exteriores y $3,61 \%$ de las interiores, mientras que el espatulado lo encontramos en el 1,2\% de las superficies exteriores (Tab. 10).

\begin{tabular}{|c|c|c|c|}
\hline Parte morfológica & $\begin{array}{c}\text { Número de } \\
\text { restos }\end{array}$ & Grosor $(\mathbf{m m})$ & $\begin{array}{c}\text { Desviación } \\
\text { típica }\end{array}$ \\
\hline Borde & 17 & 7,23 & 4,99 \\
\hline Cuello & 3 & 7,6 & 1,33 \\
\hline Base & 8 & 7,28 & 2,13 \\
\hline TOTAL & 28 & - & - \\
\hline
\end{tabular}

Tabla 9: Grosor medio en función de las distintas partes morfológicas. Average thickness according to the different morphological parts.

\begin{tabular}{|c|c|c|c|c|}
\hline \multicolumn{5}{|c|}{ Tratamiento superficial exterior } \\
\hline Raspado & Espatulado & Regularizado & No se conserva & TOTAL \\
\hline 13 & 2 & 140 & 11 & 166 \\
\hline \multicolumn{5}{|c|}{ Tratamiento superficie interior } \\
\hline \multicolumn{2}{|c|}{ Raspado } & Regularizado & No se conserva & TOTAL \\
\hline \multicolumn{2}{|c|}{6} & 150 & 10 & 166 \\
\hline
\end{tabular}

Tabla 10: Tratamientos superficiales. / Surface treatments.

Morfológicamente la parte más representada es el galbo $(75,9 \%)$, seguida de los bordes $(10,24 \%)$, las bases $(4,82 \%)$ y los cuellos $(2,41 \%)$. Las asas constituyen el 6,63\% (Fig. 20). Dentro de los 17 bordes el grupo más común es el de los bordes redondeados donde los simétricos alcanzan el 47,06\%. El 35,29\% lo configuran los bordes planos, entre los que encontramos tres oblicuos hacia el exterior, uno plano horizontal, uno plano horizontal con engrosamiento hacia el exterior y uno oblicuo hacia el exterior con engrosamiento. Resta citar tres ejemplares de bordes vueltos hacia el exterior $(17,65 \%)$. La tendencia documentada es en todos los casos exvasada. De las ocho bases, cinco son indeterminadas, dos responden a bases planas simples y una a una base plana de perfil ondulado. En función de la sección las 11 asas se clasifican en circulares $(n=5)$, bilobuladas $(n=4)$, trilobuladas $(n=1)$ y rectangulares $(n=1)$ (Fig. 21, 1 a 7 ). Esta última conserva una decoración estampillada con motivos de rectángulos con líneas verticales paralelas (Fig. 21, 4).

Solamente nueve piezas muestran algún tipo de decoración, reconociéndose la impresión en cinco ca- 


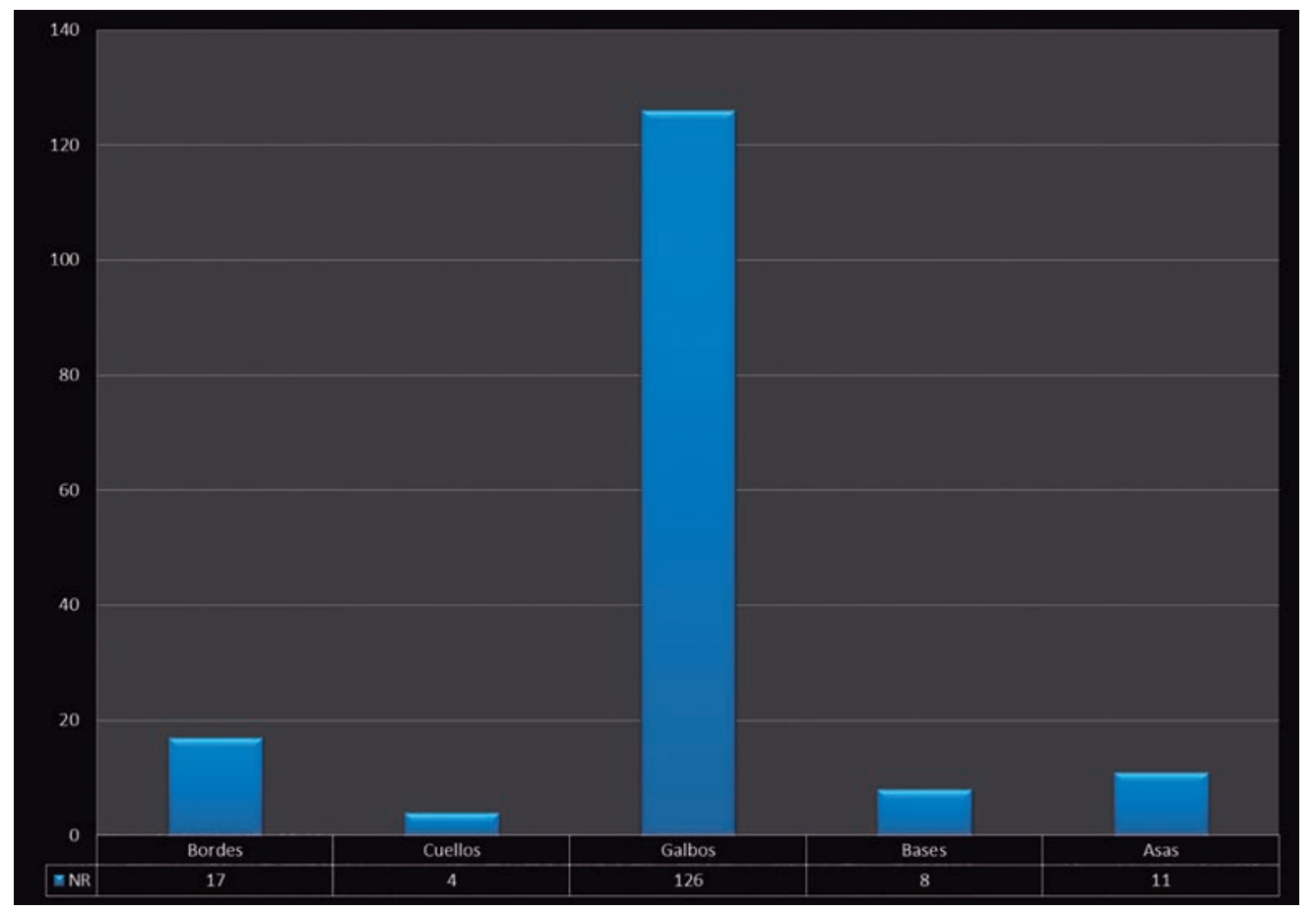

Fig. 20. Partes morfológicas. / Morphological parts of prerroman handmade pottery. sos, la incisión en tres y la combinación de técnicas en uno (Tab. 11 y 12). La impresión está representada por digitaciones, acanaladuras realizadas mediante el arrastre del dedo o la citada estampilla (Fig. 21, 9 a 12). La incisión desarrolla líneas incisas horizontales, incisiones en " $V$ " invertidas e incisiones en el labio paralelas (Fig. 21, 8 y 9). El motivo múltiple documentado combina un mamelón sobre el cual se ha realizado una digitación. (Fig. 21, 13).

\begin{tabular}{|c|c|c|}
\hline \multirow{7}{*}{ 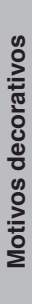 } & Digitaciones & 2 \\
\hline & Acanaladuras con el dedo & 2 \\
\hline & Estampillado rectangular con líneas verticales paralelas & 1 \\
\hline & Incisiones lineales & 2 \\
\hline & Incisiones en V invertida & 1 \\
\hline & Mamelones y digitación & 1 \\
\hline & TOTAL & 9 \\
\hline
\end{tabular}

Tabla 11: Decoraciones. / Decorations.

\begin{tabular}{|l|c|c|c|c|}
\cline { 2 - 5 } \multicolumn{1}{c|}{} & \multicolumn{4}{c|}{ Decoración } \\
\cline { 2 - 5 } \multicolumn{1}{c|}{} & Impresión & Incisión & $\begin{array}{c}\text { Impresión y } \\
\text { plástica }\end{array}$ & TOTAL \\
\hline Borde & - & 1 & - & 1 \\
\hline Galbo & 4 & 2 & 1 & 7 \\
\hline Asa & 1 & - & - & 1 \\
\hline TOTAL & 5 & 3 & 1 & 9 \\
\hline
\end{tabular}

Tabla 12: Localización de las decoraciones. / Location of decorations.
El alto grado de fragmentación ha impedido cualquier acercamiento a las formas o perfiles representados. Contamos únicamente con tres bordes que desarrollan bocas cuyos diámetros oscilan entre los $17 \mathrm{~cm}$ y los $21 \mathrm{~cm}$, uno de los cuales presenta asa (Fig. 21, 16, 18 y 19).

La cerámica a torno, con 396 fragmentos, supone el $70,46 \%$ de todo el conjunto cerámico, documentándose en todas las unidades estratigráficas (U.E.1, 18 fragmentos; U.E.2, 99 fragmentos; U.E.3, 71 fragmentos; U.E.4, 206 fragmentos; U.E.5, dos fragmentos). Los 12 bordes recuperados reflejan un grosor medio de

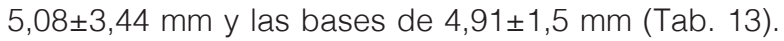
Las trazas de modelado a torno se aprecian en gran parte de las piezas, todas las cuales han sido cocidas en atmósferas oxidantes y han visto regularizadas ambas superficies.

Atendiendo a su morfología, los galbos son la parte más representada $(93,42 \%)$, con igual número de bordes y de bases (3,04\%), y dos cuellos (0,5\%) (Fig. 22). De los 12 bordes siete pertenecen al tipo de bordes

\begin{tabular}{|c|c|c|c|}
\hline Parte morfológica & $\begin{array}{c}\text { Número de } \\
\text { restos }\end{array}$ & Grosor $(\mathbf{m m})$ & $\begin{array}{c}\text { Desviación } \\
\text { típica }\end{array}$ \\
\hline Borde & 12 & 5,08 & 3,44 \\
\hline Cuello & 2 & 4,5 & 1,5 \\
\hline Base & 12 & 4,91 & 1,5 \\
\hline TOTAL & 26 & - & - \\
\hline
\end{tabular}

Tabla 13: Grosor medio en función de las distintas partes morfológicas. / Average thickness according to the different morphological parts. 

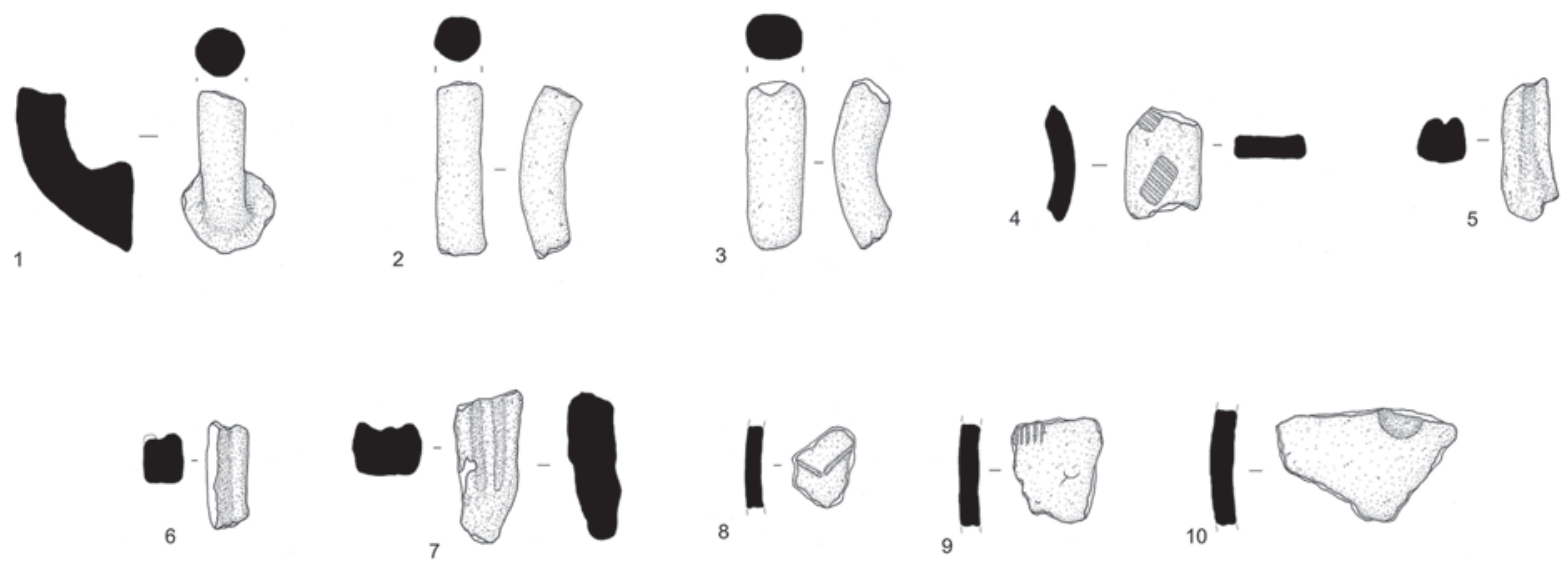

11
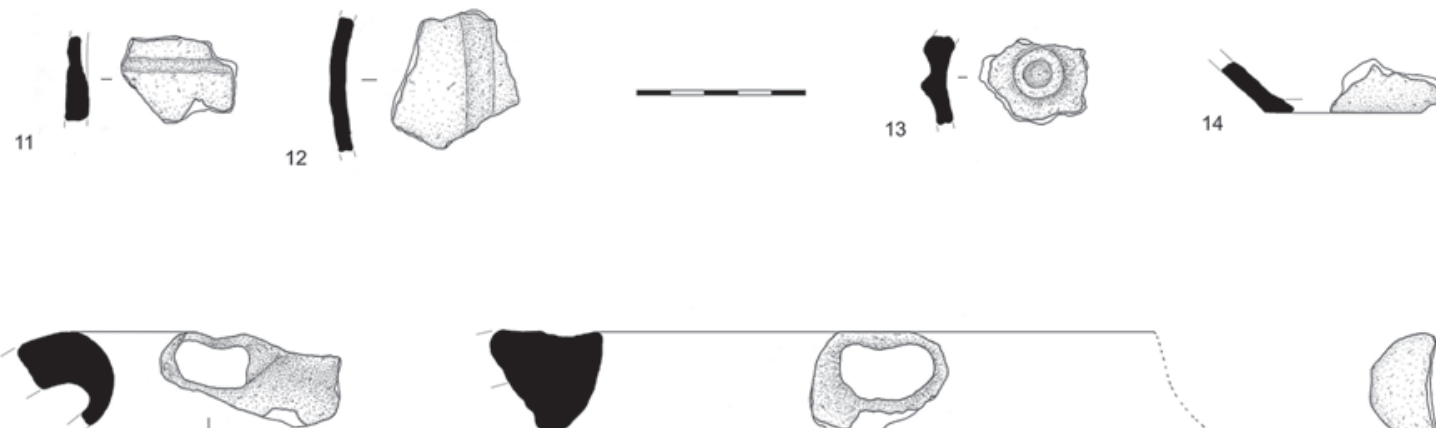

15
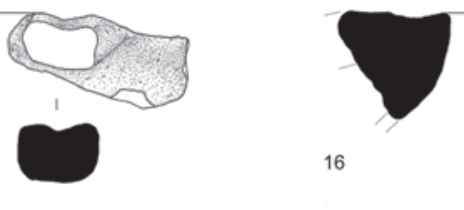

16
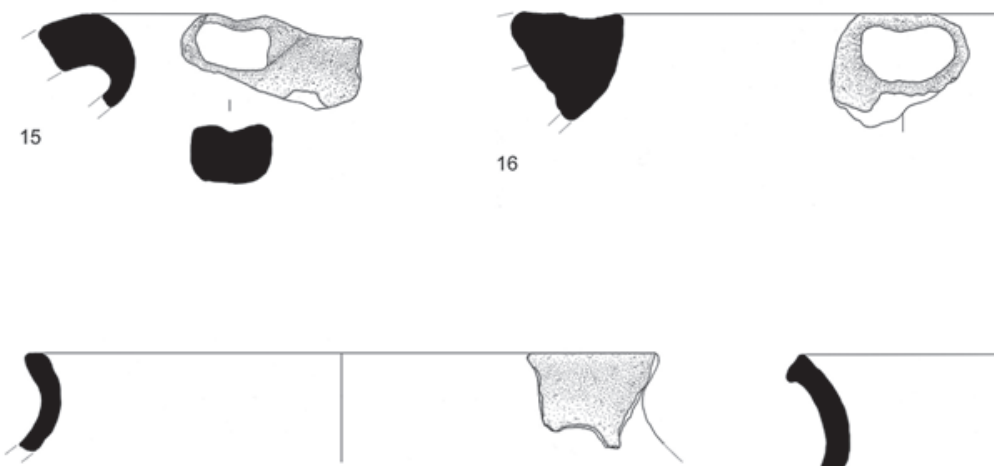

18
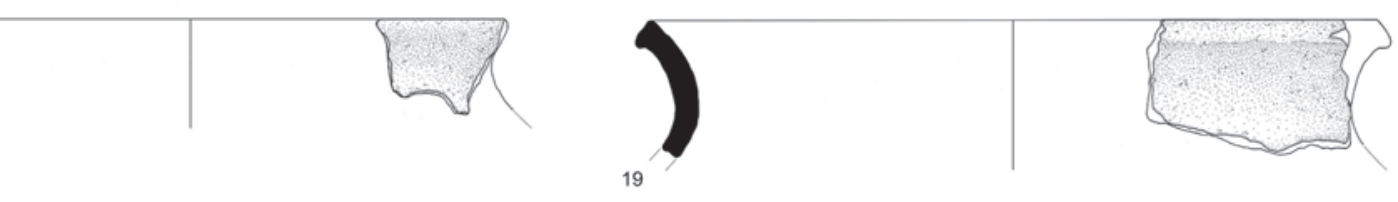

20
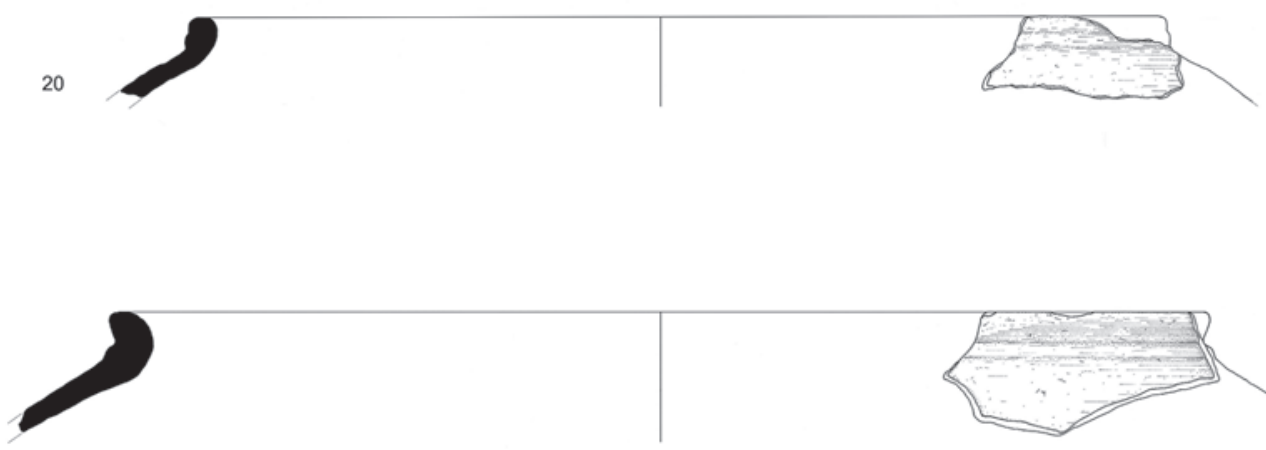

21

Fig. 21. Cerámica a mano prerromana y a torno procedente del Sondeo 1 de 2011. (Dibujos: R. Bolado del Castillo). / Handmade pottery and lathe pottery of 2011 (Drawing: R. Bolado del Castillo). 


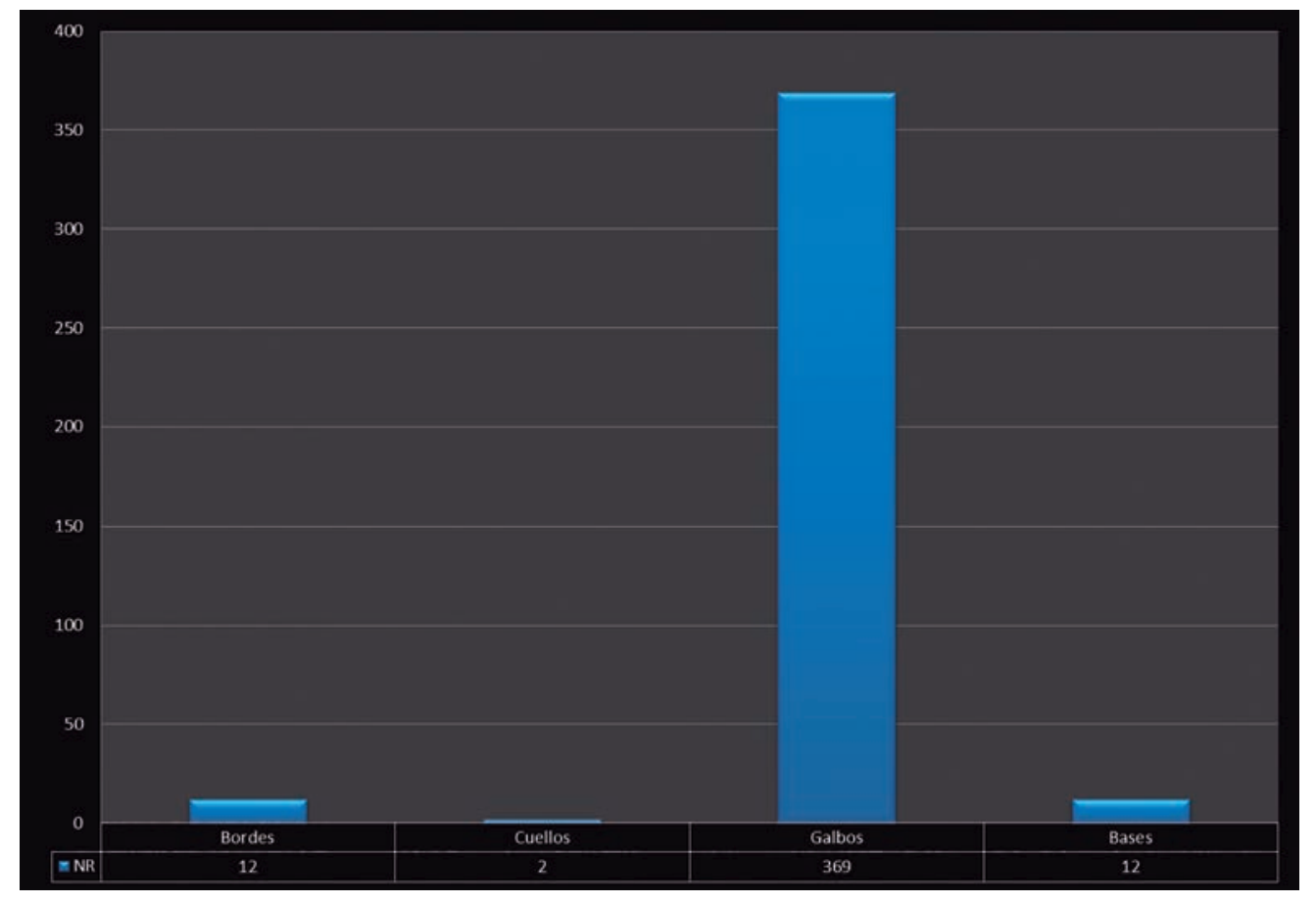

Fig. 22. Partes morfológicas. / Morphological parts of lathe pottery. vueltos hacia el exterior, dos a los bordes planos con engrosamiento hacia el exterior y uno a los bordes redondeados simétricos; los dos restantes son indeterminables. En nueve de las bases tampoco se ha podido determinar el tipo, siendo las tres restantes planas. Dos pertenecen al tipo de bases rehundidas y pie indicado, y la restante a las bases simples de fondo rehundido. La tendencia de los bordes se ha documentado en la mitad de los casos, resultando exvasada en cinco, recta en uno y entrante en otro.

No contamos con motivos decorativos ni se han podido reconstruir perfiles completos. Solo dos bordes nos permiten conocer el diámetro de sus bocas $(28 \mathrm{~cm}$ y $32 \mathrm{~cm}$ ) (Fig. 21, 20 y 21). En ambos casos presentan un engrosamiento bajo el borde lo que nos permite incluirlas en el tipo ya mencionado que relacionamos con vasijas o tinajas de almacenaje.

Por último debemos señalar la existencia de media ficha sin perforación realizada a partir de un galbo (Fig. $21,17)$.

\subsection{Objetos de bronce y hierro}

Entre los 24 objetos de bronce encontramos diversos elementos de guarnicionería, bronces indeterminables, dos fíbulas de aro sin resorte "omega" y una aguja que pudo pertenecer a estas (Fig. 23, 3, 4, 7 a 17). Las fíbulas proceden de distintos niveles estratigráficos. En la U.E.2 se recuperó un puente sin terminaciones con decoración por ambas caras a base de una banda de líneas paralelas, a modo de sogueado, que se incluye en el tipo 35.1.c de Erice (1995:207-225) o 21.2.a2 de Mariné (2001: 258-272) (Fig. 23, 5). La segunda, procedente de la U.E.4, conserva suaves acanaladuras decorativas. Forma parte del tipo 35.1.a.1 de Erice (1995:207-225) o 21.2.b1 de Mariné (2001: 258-272) (Fig. 23, 6).

Entre las 30 piezas de hierro los objetos identificados han sido también reducidos y aportan escasa información. Destacan entre otros dos fragmentos de regatón (Fig. 23, 24), placas con remache (Fig. 23, 20 y 23), un gancho (Fig. 23, 21) y una pieza de cuerpo romboidal con extremo en gancho (Fig. 23, 22).

\subsection{Otros materiales}

El grueso del registro de materiales lo conforma la fauna con 2271 restos, de los que 16 tienen una procedencia desconocida, 45 se vinculan a la U.E.1, 147 a la U.E.2, 198 a la U.E.3 y 1865 a la U.E.4. Su estudio aún no ha sido realizado, aunque sí contamos con unas identificaciones preliminares realizadas por José Yravedra. Gracias a ellas se ha podido reconocer un resto de suido en la U.E.2, dos de bóvido en el U.E.3 y, en la U.E.4, 117 de bóvido, 31 de caballo, cuatro de ciervo, dos de jabalí, 52 de ovicáprido, 57 de suidos y cuatro de perro.

Aun siendo solamente 257 los restos de fauna identificados, parecen corroborar lo conocido en otros yacimientos de la Edad del Hierro del territorio cántabro, donde existe un predominio de la ganadería basada en bóvidos y ovicápridos, seguida de los suidos y los aportes procedentes de la caza (Marín y Cisneros, 2008; Arias et al. 2010; Valle, 2010; Torres et al., 2017). 

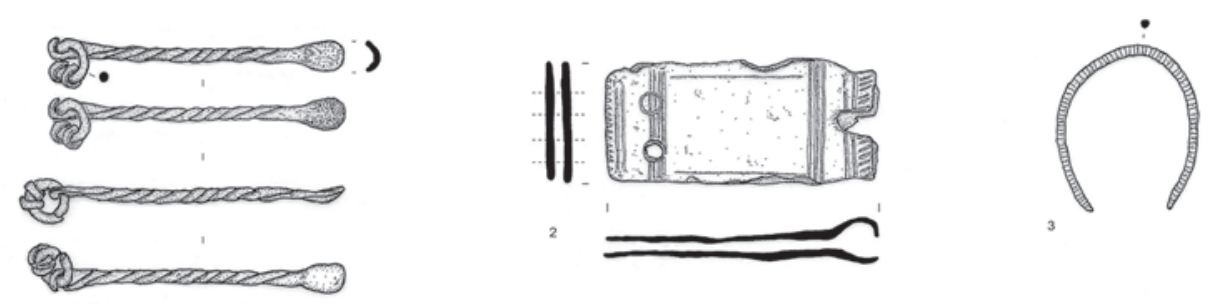

(2.)
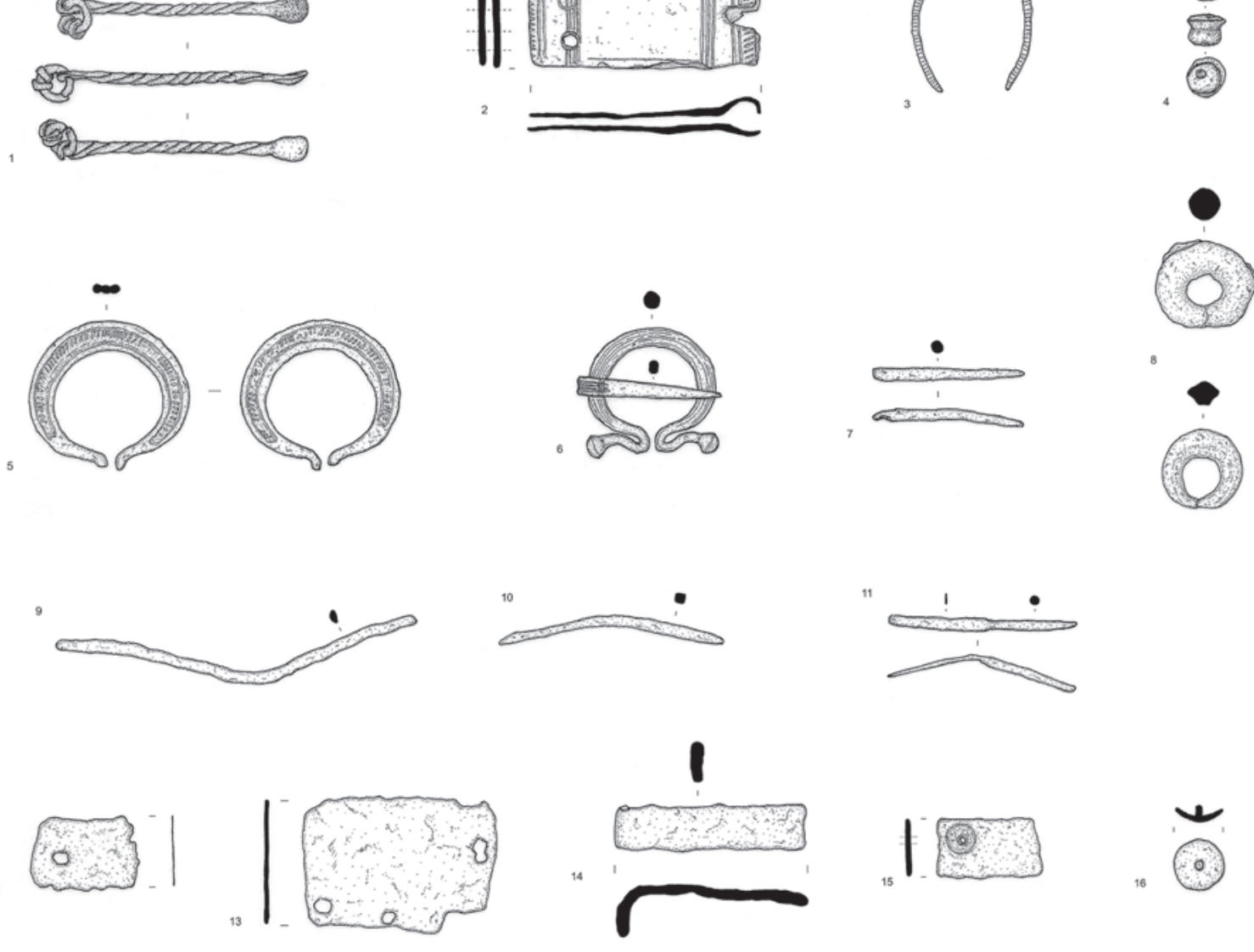

$17 \mathrm{Q}$
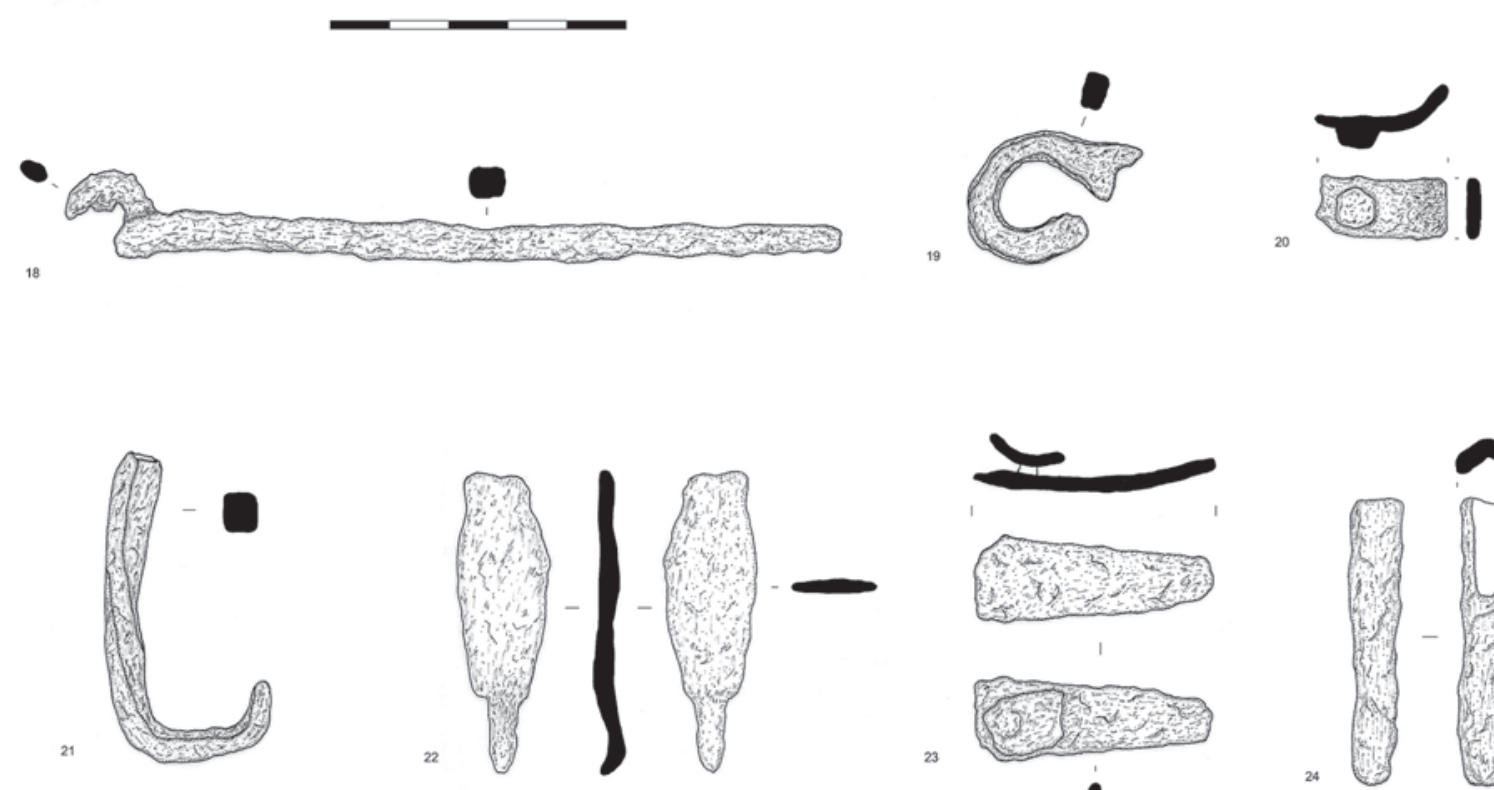

23
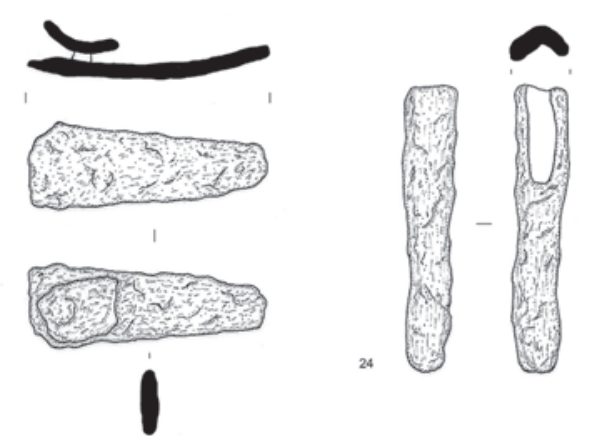

Fig. 23. Elementos metálicos prerromanos y romanos del Sondeo 1 de 2011. (Dibujos: R. Bolado del Castillo). / Prerroman and roman iron and bronze objects of 2011 (Drawing: R. Bolado del Castillo). 
Los restos de caballo también podrían responder a su consumo, aunque sería necesario un estudio más detallado de los mismos que nos permitiese desechar cualquier otra posibilidad.

Por último, debemos destacar la presencia en los cuatro primeros niveles de restos de conglomerados de pared de cabaña. Algunos son simplemente restos de barro cocido mientras que otros fragmentos conservan improntas del ramaje y una cara vista con enlucido de tonalidad blanquecina.

\subsection{Material romano}

Este grupo está representado por dos piezas de bronce, ambas procedentes de la U.E.4. La primera de ellas se trata de un oricalarium specillum, también denominado auriscalpium, de $5 \mathrm{~cm}$ de longitud, con un vástago retorcido y un extremo distal terminado en cucharita, muy común en los yacimientos romanos (Santapau, 2003: 290; Tendero y Lara, 2003: 202, 208-210; Martín y García, 2013; García y Martín, 2017) (Fig. 23, 1). En el extremo proximal se dispone una perforación donde se conserva una argolla. Esta cuenta a su vez con otras dos pequeñas argollas que estarían destinadas a otros dos útiles, los cuales, como se aprecia en los ejemplares de Corona de San Salvador (Sabiñánigo, Huesca), Bilbilis (Catalayud, Zaragoza) y Tiermes (Montejo de Tiermes, Soria), serían unas pinzas y una sonda punzante o estilete ${ }^{2}$. Su adscripción cultural es indudablemente romana, desempeñando una función de higiene personal o médico-quirúrgica.

La segunda de las piezas está conformada por un conjunto de placas rectangulares de $4,5 \times 2 \mathrm{~cm}$ destinadas a acoger un correaje de cuero, al que quedarían fijadas mediante remaches. La placa externa muestra una decoración a base de líneas incisas paralelas verticales y, en sus lados cortos, longitudinales. En uno de sus extremos ambas se vuelven hacia el interior, adoptando una forma semicircular y mostrando una escotadura central que estaría destinada a la aguja de una hebilla, posiblemente del tipo en "D" (Fig. 23, 2). Placas similares, vinculadas al mundo romano, se han hallado en los cercanos yacimientos de Monte Ornedo (Cantabria) y Retortillo (Cantabria) (Fernández Vega y Bolado, 2011: 322).

\section{LA VAGUADA DEL CASTRO DE LAS RABAS: CULTURA MATERIAL Y POSIBLES EVIDENCIAS DE VIOLENCIA}

El estudio del conjunto material recuperado en ambas campañas no esclarece por sí mismo la funcionalidad de la vaguada del castro de Las Rabas, aunque sí nos permite proponer algunas hipótesis y ahondar en aspectos tan relevantes como son la cronología y la cultura material del yacimiento.

Hasta ahora conocíamos tres interpretaciones basadas en el registro material y en la memoria de excavación existente. La más antigua planteaba que se trataba de uno de los lugares donde pudo situarse la zona de hábitat (Rincón, 1985: 186; Fraile, 1990: 132), algo que pudiera verse corroborado por la aparición de un fragmento de conglomerado de pared decorado o por lo nueve restos hallados en 2011. No obstante, la reciente intervención no ha proporcionado evidencias más sólidas al respecto, y la única cabaña que conocemos se ubica en la loma de Las Rabas, donde también de la Cata 4 de 1968-1969 proceden dos fragmentos de conglomerado, lo que, por el momento, solo nos permite afirmar que el poblamiento se dispuso por la parte superior, en la loma de Las Rabas (Bolado y Fernández Vega, 2010: 411-412; Fernández Vega et al., 2012: 224228). Los pocos restos hallados en la vaguada podrían explicarse por movimientos postdeposicionales o antrópicos, o como consecuencia de la destrucción del yacimiento durante las Guerras Cántabras.

A partir de la descripción estratigráfica de tono ceniciento y por los restos humanos, Ruiz y Muñoz (2010: 651) plantearon la posibilidad de que la Cata Tierra Julia fuera un área de necrópolis. De ser así sería plausible que esta se extendiese hacia el resto de las catas de la vaguada, situándose por un área extramuros, al modo de lo que sucede en el oppidum de Monte Bernorio (San Valero 1944, 1960; Torres et al. 2017). El sondeo practicado no ha permitido identificar evidencias de necrópolis ni de materiales que puedan relacionarse con prácticas funerarias. El análisis osteológico preliminar tampoco ha detectado nuevos restos humanos por lo que, con los datos disponibles, debemos desechar el uso de la vaguada como necrópolis. El cráneo de la Cata Tierra Julia tampoco supone un argumento a favor, pues su conservación casi completa no resulta acorde con la práctica funeraria reconocida en la Segunda Edad del Hierro, en la que el difunto era cremado y sus huesos machacados, seleccionándose solamente una parte para ser depositados con el ajuar (Lorrio, 1997: 345-348; Torres 2011: 533-538). Esta mujer adulta tuvo además un final violento en la primera mitad del siglo IV a.C., como evidencian las cuatro lesiones punzantes realizadas desde la base del cráneo. Desconocemos si su cuerpo fue abandonado en esta zona o si el cráneo procede de algún área del yacimiento donde pudo ejercer algún tipo de función. Resulta sugerente pensar en la posibilidad de que jugase un papel ritual o cultual a modo de la calota craneal femenina del Bronce final hallada en la acrópolis de Chao Sanmartín (Grandas de Salime, Asturias), o de la mandíbula de los niveles antiguos hallada en el interior de la muralla de la Campa

\footnotetext{
${ }^{2}$ Los paralelos se han extraído de la Red Digital de Colecciones de Museos d España: http://ceres.mcu.es
} 
Torres (Gijón), también posiblemente femenina. Ambas pudieran estar relacionadas con una apropiación simbólica de espacios (Mercadal, 2001; Villa y Cabo, 2003; Marín, 2011: 35). Otros restos humanos que quizás tuvieran un papel ritual son los tres individuos hallados en el interior de un torreón de Bílbilis (Catalayud, Zaragoza) (Alfayé, 2010a: 224-225), interpretados como producto de un ritual fundacional (Martín Bueno, 1975; 1982; Curchin, 2004:189-190), aunque al respecto se han formulado algunas dudas (Alfayé, 2010a: 224-225). En Ercavica (Cañaveruelas, Cuenca) se recuperaron del interior de un pozo de las termas dos cadáveres interpretados como sacrificios fundacionales (Barroso y Morín, 1997: 257, 269-270), aunque también pueden responder a enterramientos tardíos (Lorrio, 2001:113; Alfayé, 2010a: 225). En el poblado de Atxa (Vitoria, Álava) y Peñahitero (Fitero, Navarra) se ha propuesto una función profiláctica para los enterramientos de las murallas y los espacios liminales intramuros (Alfayé, 2010a: 225), mientras que en La Hoya (Laguardia, Álava), existen restos que se han relacionado con las cabezas cortadas (Llanos, 20072008), al igual que sucede en Numancia (Garray, Soria) (Taracena, 143: 163-164. Sopeña, 1987: 105) o con los cráneos expuestos de Ullastret (Gerona) (Pujol, 1979).

La exposición de cráneos en la entrada de los poblados ha sido una de las hipótesis planteadas para el cráneo de Las Rabas, dado el orificio que muestra (Torres, 2011: 401). No es descartable que alguna de las cuatro lesiones, o varias de ellas, procedan de un eventual acto de exposición, aunque parece más bien que estemos ante la evidencia de actos violentos, ya sean de origen interno -vecinal, doméstico o civil, sin excluir una posible ejecución- o fruto de un enfrentamiento entre comunidades, pero en todo caso con consecuencias fatales. En el antiguo solar de los Cántabros, historiográficamente la violencia ha sido capitalizada por las Guerras Cántabras, obviándose o enmascarando conflictos que pudieron darse con anterioridad y que, como consecuencia de una sociedad de marcado carácter guerrero, serían habituales (Quesada, 2003; García Alonso, 2015). Cabe recordar en este sentido los individuos asesinados en la Hoya durante una presunta incursión (Llanos, 2007-2008: 1275-1276).

Durante la campaña de 2010 pudimos documentar en el yacimiento los restos de una cabaña de planta circular que había sido quemada (Fernández Vega et al. 2012). En su interior, entre los pocos materiales recuperados, que advertían de una destrucción imprevista, se recogió un pequeño palo apuntado trabajado y quemado que fue datado en 2175 $\pm 30 \mathrm{BP}$ (Poz-32.924), con una calibración a dos sigma al 94,7\% que lo situaba entre el 361 y el 163 cal BC. La cabaña la fechamos por tanto entre los siglos IV-II a.C., proponiendo que fue devastada por algún accidente o quizás como consecuencia de un episodio de inestabilidad sociopolítica. Cepeda y Jiménez (2015: 175) por su parte, basándose en la datación relativa proporcionada por las placas de cinturón articuladas y en el "efecto madera vieja", desestimaron esta posibilidad y consideraron que fue destruida durante las Guerras Cántabras. Si bien es cierto que el conjunto de placas articuladas tiene sus paralelos más cercanos en los siglos II-I a.C., la posible influencia del "efecto madera vieja", en una madera de las características de la datada, no justifica la negación de la propuesta. La muerte violenta de la mujer de Las Rabas y su datación en el siglo IV a.C. podría ser una evidencia más a favor de la hipótesis de que el castro sufrió algún episodio violento. De ser así las placas articuladas podrían ser más antiguas de lo propuesto. Otra posibilidad, tampoco descartable con los escasos datos de que disponemos, es que nos hallemos ante dos episodios violentos diferentes, anteriores a las Guerras Cántabras, aunque en su momento, antes de la datación, hubiéramos relacionado el cráneo con este conflicto (Bolado et al., 2012: 176). Como puede verse, la falta de información impide ir más allá de la propuesta de hipótesis o líneas de investigación, poniendo en evidencia la necesidad de continuar con los trabajos de excavación en el yacimiento.

La última de las interpretaciones existente acerca de los restos hallados en la vaguada, es su identificación con un vertedero situado en un área que ya estaría extramuros, y que pudo funcionar como acceso natural al poblado (Bolado et al., 2010; Bolado y Fernández Vega, 2010: 409). Dicha funcionalidad explicaría el alto grado de fragmentación y el predomino de la fauna dentro del conjunto de materiales recuperado en 2011. La U.E. 4 se identificaría con el basurero, mientras que las unidades anteriores serían estratos derivados del aterrazamiento agrícola y del acondicionamiento del terreno. Esta es una práctica frecuente en la Edad del Hierro que también se documenta en el oppidum de La Ulaña (Humada, Burgos) (Marín y Cisneros, 2008: 152).

La revisión de los materiales y el nuevo sondeo ha servido igualmente para continuar avanzando en la caracterización de la cultura material del yacimiento y, por ende, de la Segunda Edad del Hierro en Cantabria. Vemos así como dentro de la colección cerámica se documentan tres tipos de producciones. Marcos García (1987-1988-1989) apuntaba que el 90\% se correspondía con cerámica a mano y el 10\% con cerámica a torno, unas proporciones que se acercan a las de los sondeos de $1968-1969$ (81,17\% y 18,38\%), pero que se invierten en el sondeo de 2011 (29,54\% y 70,46\%). Al considerar la zona como vertedero podemos trabajar con todos los datos en conjunto, lo que nos situaría ante una producción a mano del $64,17 \%$ y una producción a torno del 35,83\%.

La cerámica a mano, a nivel tecnológico, combina la cocción en atmosferas alternantes $(51,48 \%)$ y reductoras $(45,56 \%)$, existiendo un grupo minoritario oxidante $(2,96 \%)$. Todas las superficies muestran algún tipo de tratamiento habiendo una preferencia por el regularizado, que supera el $80 \%$ en ambas superficies, seguido del raspado, el espatulado o el tratamiento múltiple. El bruñido se ha documentado en 77 casos de los que 71 se hallan en la superficie exterior, algo que se explica 
al tratarse de un tratamiento funcional destinado a impedir o reducir el paso de líquidos a través de la pared mediante el cierre de los poros (Caro, 2006: 87; Orton et al., 1997: 146).

Morfológicamente la parte más representada es el galbo $(n=778)$, seguido de los bordes $(n=134)$, las bases $(n=72)$, los cuellos $(n=55)$, las asas $(n=34)$, cinco fichas y dos fragmentos de tapadera. Dentro de los bordes el $67,16 \%$ son bordes planos, con una preferencia por los planos horizontales $(55,56 \%)$ y los biselados al exterior $(26,67 \%)$. Los bordes redondeados suponen el $27,61 \%$, siendo fundamentalmente del tipo simétrico $(83,78 \%)$. De forma aislada se documentan los bordes vueltos al exterior y rebordeados al exterior. La tendencia se reparte de forma igualitaria entre la recta $(36,57 \%)$ y la exvasada $(34,33 \%)$, siendo menor la entrante $(18,66 \%)$.

Las bases son todas planas repartiéndose entre planas simples $(43,06 \%)$ y de perfil ondulado $(29,17 \%)$. Solo un ejemplar muestra pie indicado.

Por lo que respecta a la decoración, únicamente se documenta en el 6,02\% de los casos, predominando la impresión $(55,38 \%)$ frente a la incisión $(27,69 \%)$, la decoración múltiple (12,31\%) y la plástica (4,62\%). Entre los motivos impresos destacan las digitaciones y arrastres con el dedo seguido de los estampillados (sectores circulares, círculos, triángulos, etc.), mientras que la incisión se centra en las " $V$ " invertidas paralelas, las incisiones lineales o las incisiones en los labios. La combinación de motivos suele focalizarse en las incisiones en "V" invertidas rematadas en el ángulo inferior con un estampillado circular, en las incisiones en el labio con estampillados de sectores circulares en el cuerpo, en un puntillado con pellizcos, o en un mamelón con digitaciones. Entre los motivos plásticos encontramos cordones y mamelones.

La reconstrucción de perfiles completos ha sido infructuosa. Aun así hemos podido comprobar como la mayoría de las formas tienden a ser cerradas. Los diámetros de las bocas oscilan entre los $8 \mathrm{~cm}$ y los 24 cm, concentrándose el 47,69\% en el tramo $11-15 \mathrm{~cm}$, el $29,23 \%$ en el tramo $16-20 \mathrm{~cm}$, el $18,46 \%$ en el tramo $6-10 \mathrm{~cm}$ y el $4,62 \%$ en el tramo $21-24 \mathrm{~cm}$. El diámetro de las bases se distribuye entre los $5 \mathrm{~cm}$ y los $29 \mathrm{~cm}$, concentrándose la mayoría en el tramo 6-10 cm (64,52\%) y $11-15 \mathrm{~cm}(22,58 \%)$. Desde el punto de vista formal hemos distinguido un total de siete tipos de mediano y pequeño tamaño, entre los que destacan vasos, cuencos, jarras y ollas, además de tapaderas.

Las características de la producción a mano nos permiten situarla en la Segunda Edad del Hierro, no existiendo ninguna forma o decoración que nos remita a momentos anteriores (Cubas et al., 2013). Con las fechas de que disponemos, tanto absolutas como relativas, no consideramos que sea anterior al siglo IV a.C. ni supere el siglo I a.C. Paralelos para esta colección, a nivel formal y decorativo, los podemos encontrar en los yacimientos de Monte Bernorio (Villarén, Palencia) (Torres et al., 2012), La Loma (Santibáñez de la Peña, Palencia) (Peralta, 2015) o La Ulaña (Humada, Burgos) (Álvarez, 2005; Cisneros et al. 2011), donde su producción a mano se inicia en el siglo IV a.C.

La cerámica a torno, por su parte, se caracteriza a nivel tecnológico por contar con un porcentaje de superficies regularizadas superior al 98\%, con escasas evidencias de raspado o bruñido. La parte morfológica más representada es el galbo $(n=561)$, seguido de los bordes $(n=21)$, las bases $(n=15)$, los cuellos $(n=5)$ y una ficha. Entre los bordes el 30,09\% corresponde al tipo redondeado, bien simétrico $(62,5 \%)$, asimétrico al interior (25\%) o asimétrico hacia el exterior (12,5\%). Tras ellos el 33,33\% lo conforman los bordes vueltos hacia el exterior, existiendo de forma aislada ejemplos de bordes planos engrosados y bordes rebordeados al exterior.

De las 15 bases solo cuatro, planas, nos permiten conocer su tipo. Dos pertenecen al tipo de fondos rehundidos e indicados, una al de fondo rehundido simple y la restante al de perfil ondulado con acanaladura inferior.

La decoración constituye una singularidad: se conserva en el 1,33\% de las piezas $(n=8)$. En cinco de ellas se aprecia decoración pintada mientras que las tres restantes cuentan con incisiones: en dos casos circundarían la pieza al compás del movimiento del torno mientras que, en el tercero, la decoración ha sido realizada sobre un galbo reaprovechado, mostrando motivos lineales aleatorios. La decoración pintada desarrolla motivos lineales, uno zoomorfo y vegetal que combina un ave con un árbol, y una representación astral mediante una esvástica.

Las formas identificadas son en su mayoría cerradas, habiéndose podido documentar cómo parte de los bordes oscilan entre los $12 \mathrm{~cm}$ y los $32 \mathrm{~cm}$. Se han podido distinguir seis formas entre las que destacan cuencos, vasijas carenadas y tinajas.

Por lo que respecta a su cronología, la cerámica a torno se fecha en el territorio cántabro entre los siglos IV/III-I a.C. (Cubas et al. 2013), pudiendo encontrar paralelos de las tinajas y las vasijas carenadas en la Ulaña (Álvarez, 2015: 106-111), Monte Ornedo (Valdeolea, Cantabria) (Fernández Vega et al., 2014: 181), Dessobriga (Palencia y Burgos) (Misiego et al. 2003: 66) o Monte Bernorio (Torres et al., 2012: 146). Las esvásticas y los motivos zoomorfos resultan también comunes en estos momentos avanzados de la Edad del Hierro, documentándose por toda la Celtiberia y territorio vacceo (Wattenberg, 1963; Lorrio, 1997: 239-247; Sanz Mínguez et al., 2003; Alfayé, 2010b: 558).

La diferente proporción dentro del conjunto entre ambas producciones ha hecho que la cerámica a mano se considere como una producción local, mientras que la cerámica a torno se valore como fruto de la importa- 
ción, bien de las vasijas o del producto que contenían. A este respecto, aunque no hay evidencias de talleres $u$ hornos en el poblado, el hallazgo de un posible fragmento de parrilla de un horno de doble cámara en Monte Bernorio (Torres et al., 2012: 145-146) abre la posibilidad a que su procedencia, si no local, no sea tan lejana. Aunque inferior al de la cerámica a mano, el porcentaje de la producción a torno es significativo, lo que indica que no se trataría de un producto de uso poco común.

Algo distinto sucede con los fragmentos de cerámica campaniense, pues no suponen más del 0,3\% de la colección estudiada. Un tipo de vasija que sí podría ser de singular importancia para su poseedor, fechándose en los siglos II-I a.C. Sus formas nos Ilevan a identificarlas como cerámica campaniense, no obstante la falta de conservación del barniz, fruto de su baja calidad, hace que nos planteemos cada vez más que estemos ante imitaciones procedentes de los valles del Ebro o del Duero (Mínguez y Sáenz, 2007; Adroher y Caballero, 2012).

El conjunto metálico, a pesar de lo reducido de su número, depara objetos diversos, relacionados con las actividades cotidianas del poblado. Tenemos por ejemplo regatones y un fragmento de punta de lanza relacionados con el mundo guerrero, al que podrían unirse múltiples de los elementos de guarnicionería; agujas vinculadas con el trabajo textil, una azada para el trabajo de la tierra o un campano que, junto con los datos extraídos de los restos de fauna, nos hablan de una actividad ganadera centrada en los bóvidos y ovicápridos y, en menor medida, suidos, complementándose con el aporte de la caza, como prueban los restos de jabalí y ciervo.

A nivel cronológico el grupo de fíbulas es el que mayor información nos aporta. De las 11 recuperadas cuatro se corresponden con ejemplares de La Tène o de apéndice caudal y ocho se incluyen en las fíbulas de aro sin resorte "omega". Según la clasificación de Argente, las fíbulas de La Tène pertenecen al tipo 8A y 8A2 (Argente, 1994: 84-95), el último de los cuales se fecha entre mediados del siglo IV a.C y finales del siglo II a.C. Las fíbulas de aro sin resorte "omega" por su parte, según Mariné (2001: 258-275) pueden ser una creación autóctona del siglo I a.C. De esta forma, uniendo las dataciones absolutas a las relativas, se confirma que el enclave mantuvo una ocupación entre el siglo IV a.C. y las Guerras Cántabras. En este momento el castro fue asaltado, dejando como prueba de ello distintos materiales militares romanos (Fernández Ibáñez, 2006: 261 y 263; Bolado et al., 2010: 89-91; Fernández Vega et al., 2012), a los que debemos sumar ahora unas placas rectangulares de correaje y un oricalarium specillum. Este final bélico, parece que no fue el único episodio traumático que sufrió el castro, pues en el siglo IV a.C. se constata la cruenta muerte de una mujer adulta, y también se conoce la destrucción de una cabaña. El registro arqueológico del castro ilustra así una vida cotidiana que en distintos momentos se vio sorprendida y, al final, interrumpida abruptamente.

\section{AGRADECIMIENTOS}

Este trabajo no hubiera sido posible sin la colaboración de los arqueólogos Lino Mantecón y Joaquín Callejo.

\section{BIBLIOGRAFÍA}

Acssadi, G., Nemeskeri, J., 1970. History of Human Life Span and Mortality. Akadémiai Kiado. Budapest.

Adroher Auroux, A.M., Caballero Cobos, A., 2012. Imitaciones de campaniense en el mediodía peninsular. La cerámica gris bruñida republicana. In: Bernal, D., Ribera, A. (eds.) Cerámicas hispanorromanas II. Producciones regionales, 23-38. Universidad de Cádiz.

Aja, J.R., Cisneros Cunchillos, M., Diez Castillo, A., López Noriega, P., 1999. El poblamiento de montaña en el sector central de la Cordillera Cantábrica. Fuentes escritas y arqueológicas. El ejemplo de la comarca de la Braña (Palencia). BAR Internationals Series, 759 .

Alfayé Villa, S., 2010a. Ritos de sangre: sacrificios cruentos en los ámbitos celtibérico y vacceo. In: Burillo, F. (coord.) VI Simposio sobre los Celtíberos. Ritos y mitos, 219-238. Centro de Estudios Celtibéricos de Segeda.

Alfayé Villa, S., 2010b. Iconografía vaccea: una aproximación a las imágenes del territorio vacceo. In: Romero, F. y Sanz, C. (eds.) De la Región Vaccea a la Arqueología Vaccea, 547-573. Universidad de Valladolid.

Álvarez Santos, J.A., 2005. La cerámica. In: Cisneros, M., López, P. (eds) El castro de La Ulaña (Humada, Burgos). La documentación arqueológica (1997-2001), 105-114. Universidad de Cantabria.

Argente Oliver, J.L., 1994. Las fíbulas de la Edad del Hierro en La Meseta Oriental. Valoración tipológica, cronológica y cultural. Excavaciones Arqueológicas en España, Instituto de Conservación y Restauración de Bienes Culturales, Madrid.

Arias Cabal, P., Ontañón Peredo, R., Cepeda Ocampo, J.J., Pereda Saiz, E., Cueto Rapado, M., 2010. Castro del Alto de la Garma (Omoño, Ribamontán al Monte). In: Serna, L., Martínez, A., Fernández, V. (coords.), Castros y Castra en Cantabria. Fortificaciones desde los orígenes de la Edad del Hierro a las guerras con Roma. Catálogo, revisión y puesta al día, 501-514. ACANTO.

Bolado del Castillo, R., Cubas, M., Cepeda, J.J., Pereda Saiz, E., Ontañón Peredo, R., Arias Cabal, P., 2015. Aportación al estudio del Alto de la Garma (Cantabria): las cerámicas de la Primera Edad del Hierro. Zephyrus LXXV, 125-140

Bolado del Castillo, R., Fernández Vega, P.A., 2010. Castro de Las Rabas (Cervatos, Campoo de Enmedio). In: Serna, L., Martínez, A. y Fernández, V. (coords.), Castros y Castra en Cantabria. Fortificaciones desde los orígenes de la Edad del Hierro a las guerras con Roma. Catálogo, revisión y puesta al día, 403-428. ACANTO.

Bolado del Castillo, R., Fernández Vega, P.A., Callejo Gómez, J., 2010. El recinto fortificado de El Pedrón (Cervatos, Cantabria), los campamentos de La Poza (Campoo de Enmedio, 
Cantabria) y el castro de Las Rabas: un nuevo escenario de las Guerras Cántabras. Kobie Paleoantropología 29, 85-108.

Bolado del Castillo, R., Gutiérrez Cuenca, E., Hierro Gárate, J.A., 2012. Las Guerras Cántabras. Cántabros. Origen de un pueblo. Asociación para la Defensa de los Intereses Cántabros y Consejería de Educación, Cultura y Deporte del Gobierno de Cantabria, 95-202.

Brigth, L., 2011. Taphonomic signatures of animal scavenging in northern California: a forensic anthropological analysis. Degree Master of Arts in Anthropology. A Thesis Presented to the Faculty of California State University, Chico.

Bronk Ramsey, C., 2001. Development of the radiocarbon calibration program. Radiocarbon 43, 355-363.

Bronk Ramsey, C., 2009. Bayesian analysis of radiocarbon dates. Radiocarbon 51, 337-360.

Brothwell, D.R., 1965. Dental wear patterns in the Libben Population. American Journal of Physical Anthropology 68, 47-56.

Camarós, E., Cueto, M., Lorenzo, C., Villaverde, V., Rivals, F., 2015. Large carnivore attacks on hominins during the Pleistocene: a forensic approach with a Neanderthal example. Archaeological and Anthropological Sciences 8(3), 635-646.

Campillo, D., 1993. Paleopatología. Los Primeros Vestigios de la Enfermedad. Fundación Uriach, 1938. Colección Historia de las Ciencias de la Salud.

Caro, A., 2006. Ensayo sobre cerámica en Arqueología. Cádiz.

Cepeda Ocampo, J.J., Jiménez Chaparro, J.I., 2015. Los campamentos de La Poza y el Castro de Las Rabas revisitados. Campoo de En medio, Cantabria. In: Camino, J., Peralta, E.J., Torres, J.F. (coords.) Las Guerras Astur-Cántabras, 169179. Gijón.

Cisneros Cunchillos, M., García Sánchez, J., Hernández Domínguez, I., 2011. Los oppida del sector central de la cordillera cantábrica: síntesis y nuevas investigaciones.

Cubas, M., Bolado del Castillo, R., Pereda Rosales, E. M., Fernández Vega, P.A., 2013. La cerámica en Cantabria desde su aparición (5000 cal BC) hasta el final de la Prehistoria: técnicas de manufactura y características morfo-decorativas. Munibe Antropologia-Akeologia 64, 5-24.

Curchin, L., 2004. The Romanization of Central Spain. London-New York.

Erice Lacabe, R., 1995. Las fíbulas del nordeste de la Península Ibérica: siglos I a.E. al d.E. Institución Fernando El Católico, Zaragoza.

Fernández Ibáñez, C., 2006. Post vestigium exercitus. Militaria romana en la región septentrional de la Península Ibérica durante la época altoimperial. In Morillo, A. (coord.) Arqueología Militar Romana en Hispania II: producción y abastecimiento en el ámbito militar, 257-308. Universidad de León.

Fernández Vega, P.A., Bolado del Castillo, R., 2011. El recinto campamental romano de Santa Marina (Valdeolea, Cantabria): un posible escenario de las Guerras Cántabras. Resultados preliminares de la campaña de 2009. Munibe Antropologia-Arkeologia 62, 303-339.

Fernández Vega, P.A., Bolado del Castillo, R., Callejo Gómez, J., Mantecón Callejo, L., 2012. El castro de Las Rabas (Cervatos, Cantabria) y las Guerras Cántabras: resultados de las intervenciones arqueológicas de 2009 y 2010. Munibe Antropologia-Arkeologia 63, 213-253.
Fernández Vega, P.A., Mantecón Callejo, L., Callejo Gómez, J., Bolado del Castillo, R., 2014. La sauna de la Segunda Edad del Hierro del oppidum de Monte Ornedo (Cantabria, España). Munibe Antropologia-Akeologia 65, 177-195.

Fraile López, M.A., 1990. Historia social y económica de Cantabria hasta el siglo X. Ed. Miguel ángel fraile, Reinosa.

García Alonso, F., 2015. Cabezas cortadas y rituales guerreros en la Protohistoria del Nordeste Peninsular. In: Vidal, J., Antela, B (eds.), Guerra y Religión en el Mundo Antiguo, 25-110. Libros Pórtico.

García Carretero, J.R., Martín Ruiz, J.A. (2017). Material médico-quirúrgico romano hallado en Osuna (Sevilla). Anales de Arqueología Cordobesa 28, 181-190.

García Guinea, M. A., Rincón, R., 1970. El asentamiento cántabro de Celada Marlantes. Instituto de Prehistoria y Arqueología "Sautuola". Institución Cultural de Cantabria. Diputación Provincias de Santander.

García Guinea, M.A., 1999. Significado de la excavación arqueológica en el castro de las Rabas (Celada Marlantes). Regio Cantabrorum. Santander, 99-106.

Llanos, A., 2007-2008. El rito de las cabezas cortadas en el poblado de La Hoya. Veleia 24-25 (vol II), 1273-1281.

Lorrio, A.J., 1997. Los Celtíberos. Complutum Extra 7. Universidad Complutense de Madrid y Universidad de Alicante.

Lorrio, A., 2001. Ercavica. La muralla y la topografía de la ciudad. Madrid.

Marcos García, M. A., 1985. Revisión y estudio de los materiales arqueológicos del yacimiento de Celada Marlantes conservados en el Museo Regional de Prehistoria y Arqueología. Universidad de Cantabria. Inédita.

Marcos García, M.A., 1987-1988-1989. La cerámica como fuente para el conocimiento histórico-etnográfico de Cantabria en la antigüedad. Publicaciones del Instituto de Etnografía y Folclore Hoyos Sainz XIII, 234-244.

Marín Arroyo, A.B., Cisneros Cunchillos, M., 2008. Consideraciones económicas sobre el oppidum de la Ulaña (Humada, Burgos): la explotación ganadera. Zephyrus LXII, 151-162.

Marín Suárez, C., 2011. De nómadas a castreños: el primer milenio antes de la era en el sector centro-occidental de la cordillera cantábrica. Tesis Doctoral.

Mariné Isidro, M., 2001. Fíbulas romanas en Hispania: la Meseta. Anejos de Archivo Español de Arqueología XXIV. CSIC, Madrid.

Martín Bueno, M., 1975. Bilbilis: enterramientos indígenas en la torre de la muralla. XIII Congreso Nacional de Arqueología, 701-706. Zaragoza.

Martín Ruiz, J.A., García Carretero, J.R., 2013. Instrumental médico de época romana procedente de Carmona conservado en el Museo Municipal de Pizarra (Málaga). Ligustinus 2, 15-24.

Mercadal i Fernández, O., 2001. Estudio paleopatológico de un resto óseo procedente de la Campa Torres (Gijón). In: Maya, J.L., Cuesta F. (eds.), El castro de la Campa Torres. Periodo prerromano, 289-294. VTP Editorial.

Mínguez Morales, J.A., Sáenz Preciado, C., 2007. Imitaciones de cerámicas de barniz negro campanienses y de terra sigillata en producciones autóctonas del valle medio del Ebro. In: Roca, M., Principal, J. (coords.) Les imitacions de vaixella fina 
importada a la Hispania Citerior (segles I aC-I dC), 235-257. Institut Català d’Arqueologia Clàssica.

Misiego Tejada, J.C., Martín Carbajo, M.A., Marcos Contreras, G.J., Sanz García, F.J., Redondo Martínez, R., Doval Martínez, M., García Rivero, P.F., García Martínez, M.I., 2003. Excavación arqueológica en el poblado protohistórico de Dessobriga (Osorno, Palencia/Melgar de Fernamental, Burgos). In: Misiego, J.C., Etxeberría, C. (coords.), Actuaciones arqueológicas en la autovía del Camino de Santiago (A-231, León-Burgos). Provincia de Burgos (2000-2003), 31-92. Junta de Castilla y León.

Orton, C., Tyeres, R., Vince, A., 1997. La cerámica en arqueología. Crítica Grijalbo Mondadori, Barcelona.

Peralta Labrador, E., 2007. Equipamiento militar romano de la conquista de la antigua Cantabria. Sautuola XIII, 493-511.

Peralta Labrador, E. 2015. El asedio de La Loma (Santibáñez de la Peña, Palencia) y otros campamentos romanos del norte de Castilla. In: Camino, J., Peralta, E.J., Torres, J.F. (coords.) Las Guerras Astur-Cántabras, 91-109. Gijón.

Pujol Puigvehí, A., 1979. Los cráneos de Ullastret y su posible significado. Pyrenae 15-16: 267-279.

Quesada, F., 2003. La guerra en las comunidades ibéricas (c.237-c.195 a.C.): un modelo interpretativo. In Morillo, A., Cadiou, F. y Mourcade, D. (eds.), Defensa y territorio en Hispania de los Escipiones a Augusto: espacios urbanos y rurales, municipales y provinciales, 101-156. León.

Reimer, P.J., Bard E, Bayliss, A., Beck J.W., Blackwell P.G., Bronk Ramsey, C., Buck C.E., Cheng, H., Edwards, R.L., Friedrich. M, Grootes. P.M., Guilderson, T.P., Haflidason, H., Hajdas, I., Hatté, C., Heaton, T.J., Hoffmann, D.L., Hogg, A.G., Hughen, K.A., Kaiser, K.F., Kromer, B., Manning, S.W., Niu, M., Reimer, R.W., Richards, D.A., Scott, E.M., Southon, J.R., Staff, R.A., Turney, C.S.M., Van der Plicht, J., 2013. IntCal13 and Marine13 radiocarbon age calibration curves $0-50,000$ years cal BP. Radiocarbon 55(4), 1869-1887.

Rincón Vila, R., 1985. Las Culturas del metal. In García Guinea, M. (Dir.) Historia de Cantabria. Prehistoria. Edades Antigua y Media. Estvdio, 113-240.

Robins y Cotran, 2007. Patología Estructura y Funcional. $7^{\text {a }}$ Edición. Elsevier.

Ruiz Cobo, J., Muñoz Fernández, E., 2010. Yacimientos no castreños de la protohistoria y antigüedad en Cantabria: vertederos y hábitats. In: Serna, L., Martínez, A., Fernández, V. (coords.), Castros y Castra en Cantabria. Fortificaciones desde los orígenes de la Edad del Hierro a las guerras con Roma. Catálogo, revisión y puesta al día, 650-675. ACANTO.

San Valero Aparisi, J., 1944. Excavaciones Arqueológicas en Monte Bernorio (Palencia). Primera Campaña, 1943. Informes y Memorias 5. Ministerio de Educación Nacional, Madrid.

San Valero Aparisi, J. 1960. Monte Bernorio. Aguilar de Campoo (Palencia). Campaña de Estudio de 1959. Excavaciones Arqueológicas en España 44. Ministerio de Educación Nacional, Madrid.

Santapau, M.C., 2003. Instrumental médico-quirúrgico de Segóbriga (Saelices, Cuenca). Hallazgos de las campañas de excavación 1999-2002. Bolskan 20, 287-295.

Sanz Mínguez, C., Gallardo, M.A., Velasco, J., Centeno, I., 2003. La tumba 75 de Las Ruedas, primer testimonio arqueológico de la elite ecuestre vaccea. In: Sanz, C., Velasco, J. (eds.), Pintia. Un oppidum en los confines orientales de la región vaccea, Universidad de Valladolid, 173-196.

Sopeña Genzor, G., 1987. Dioses, ética y ritos. Aproximaciones para una comprensión de la religiosidad entre los pueblo celtibéricos. Universidad de Zaragoza.

Taracena, B., 1943. Cabezas-trofeo en la España céltica. Archivo Español de Arqueología 16, 157-171.

Tendero, M., Lara, G., 2003. Materiales higiénico-sanitarios de Ilici (La Alcudia, Elche, Alicante). Bolskan 20, 201-214.

Torres Martínez, J.F., Martínez Velasco, A., De Luis Mariño, S., 2012. El oppidum de Monte Bernorio en la Cantabria Histórica. Nueve siglos de Historia. Kobie. Serie Paleoantropología 31, 137-156.

Torres Martínez, J.F., Martínez Velasco, A., Pérez Farraces, 2013. Los proyectiles de artillería romana en el oppidum de Monte Bernorio (Villarén, Palencia) y las campañas de Augusto en la primera fase de la guerra cantábrica. Gladius XXXIII, 57-80.

Torres Martínez, J.F., Hamann, C., Fuentes, A., Fernandes, R., Domínguez Solera, S., Martínez Velasco, A., Rodríguez Trigo, A., Serna Gancedo, A., Sobremazas Martínez, A.M., 2017. El fenómeno funerario en la Edad del Hierro del cantábrico. Un nuevo espacio ritual en la necrópolis de Monte Bernorio (campañas de excavación de 2007 y 2008). Lvcentvm, XXXVI, 105-128.

Valle Gómez, A., 2010. Castro de Castilnegro (Medio Cudeyo-Liérganes). In: Serna, L., Martínez, A., Fernández, V. (coords.), Castros y Castra en Cantabria. Fortificaciones desde los orígenes de la Edad del Hierro a las guerras con Roma. Catálogo, revisión y puesta al día, 473-488. ACANTO.

Villa Valdés, A., Cabo Pérez, L., 2003. Depósito funerario y recinto fortificado de la Edad del Bronce en el castro de Chao Samartín: argumentos para su datación. Trabajos de Prehistoria 60(2), 143-151.

Wattenberg Sanpere, F., 1963. Las cerámicas indígenas de Numancia. Instituto Español de Prehistoria, Madrid. 